\title{
Plio-Quaternary tectonic evolution of the southern margin of the Alboran Basin (Western Mediterranean)
}

\author{
Manfred Lafosse ${ }^{1,2}$, Elia d'Acremont ${ }^{1}$, Alain Rabaute ${ }^{1}$, Ferran Estrada ${ }^{3}$, Martin Jollivet-Castelot ${ }^{4}$, \\ Juan Tomas Vazquez ${ }^{5}$, Jesus Galindo-Zaldivar ${ }^{6,7}$, Gemma Ercilla ${ }^{3}$, Belen Alonso ${ }^{3}$, Jeroen Smit ${ }^{2}$, Abdellah Ammar ${ }^{8}$, \\ and Christian Gorini ${ }^{1}$ \\ ${ }^{1}$ Institut des Sciences de la Terre Paris, ISTeP UMR 7193, INSU-CNRS, Sorbonne Université, 75005 Paris, France \\ ${ }^{2}$ Tectonic and Structural Geology groups, Department of Earth Sciences, Utrecht University, P.O. Box 80.021, \\ 3508 TA Utrecht, the Netherlands \\ ${ }^{3}$ Instituto de Ciencias del Mar, ICM-CSIC, Continental Margin Group, 08003 Barcelona, Spain \\ ${ }^{4}$ Labratoire d'Océanologie et de Géosciences (LOG), Univ. Lille, CNRS, Univ. Littoral Côte d'Opale, UMR 8187, \\ 59000, Lille, France \\ ${ }^{5}$ Juan-Tomas Vazquez, Instituto Español de Oceanografía, Centro Oceanográfico de Málaga, 29640 Fuengirola, Spain \\ ${ }^{6}$ Dpto. de Geodinámica, Universidad de Granada, Granada, Spain \\ ${ }^{7}$ Instituto Andaluz de Ciencias de la Tierra (CSIC-UGR), Granada, Spain \\ ${ }^{8}$ Département de Géologie, Faculté des Sciences, Université Mohammed V, Avenue Ibn-Batouta, B. P. 1014, Rabat, Morocco
}

Correspondence: Manfred Lafosse (m.r.lafosse@uu.nl)

Received: 19 July 2019 - Discussion started: 26 July 2019

Revised: 10 March 2020 - Accepted: 11 March 2020 - Published: 30 April 2020

\begin{abstract}
Progress in the understanding and dating of the sedimentary record of the Alboran Basin allows us to propose a model of its tectonic evolution since the Pliocene. After a period of extension, the Alboran Basin underwent a progressive tectonic inversion starting around 9-7.5 Ma. The Alboran Ridge is a NE-SW transpressive structure accommodating the shortening in the basin. We mapped its southwestern termination, a Pliocene rhombic structure exhibiting series of folds and thrusts. The active Al-Idrissi Fault zone (AIF) is a Pleistocene strike-slip structure trending NNESSW. The AIF crosses the Alboran Ridge and connects to the transtensive Nekor Basin and the Nekor Fault to the south. In the Moroccan shelf and at the edge of a submerged volcano we dated the inception of the local subsidence at 1.811.12 Ma. The subsidence marks the propagation of the AIF toward the Nekor Basin. Pliocene thrusts and folds and Quaternary transtension appear at first sight to act at different tectonic periods but reflect the long-term evolution of a transpressive system. Despite the constant direction of AfricaEurasia convergence since $6 \mathrm{Ma}$, along the southern margin of the Alboran Basin, the Pliocene-Quaternary compression evolves from transpressive to transtensive along the AIF and
\end{abstract}

the Nekor Basin. This system reflects the logical evolution of the deformation of the Alboran Basin under the indentation of the African lithosphere.

\section{Introduction}

The Pliocene-Quaternary tectonics of the Alboran Basin and its margins show the superposition of transpressive and transtensive structures that have been attributed to different mechanisms including changes in far-field stress, slab rollback and mantle delamination (Calvert et al., 2000; Gutscher et al., 2002; Martínez-García et al., 2013, 2017; Petit et al., 2015; Thurner et al., 2014). At present day, GPS velocities define an Alboran tectonic domain in between the African and Iberian rigid blocks (Fig. 1) (Neres et al., 2016; Palano et al., 2013, 2015). Based on the seismicity (Fig. 2), a present-day diffuse plate boundary between Africa and Eurasia was proposed in the Alboran Basin and the Betic-Rif belt (Bird, 2003; Neres et al., 2016; Palano et al., 2015). DeMets et al. (2015) constrained the location of the rotation poles between Eurasia, North America and Africa since the Miocene. 
They show that since 5.2 Ma, the southeastward migration of the rotation pole between Africa and Eurasia results in a roughly constant direction of convergence and an increase in the convergence rate (from $\sim 3.5$ to $\sim 5.5 \mathrm{~mm} \mathrm{yr}^{-1}$ at $35^{\circ} \mathrm{N}, 5^{\circ} \mathrm{W}$ ). More recently, Spakman et al. (2018) showed that from $8 \mathrm{Ma}$ to the present day, the Africa-Eurasia absolute convergence has produced $15 \mathrm{~km}$ of relative motion in the NNE-SSW direction. These reconstructions question the idea of a change in plate kinematics as the cause for changes in tectonic evolution in the Alboran tectonic domain (Martínez-García et al., 2013). Lithosphere-scale processes and crustal heterogeneities such as mantle and lower crustal delamination have exerted a strong influence on the deformation and the structure of the Alboran Basin (Petit et al., 2015; Thurner et al., 2014). The mechanical coupling between the Alboran Domain and the subsiding lithosphere and/or slab dragging under Africa-Eurasia convergence have caused the extrusion of the Betic-Rif belt toward the southwest (Neres et al., 2016; Perouse et al., 2010; Petit et al., 2015; Spakman et al., 2018; Thurner et al., 2014).

Plio-Quaternary changes in stress directions have been demonstrated in the Betic-Rif belt from field geology (Ait Brahim and Chotin, 1990; Galindo-Zaldívar et al., 1993; Giaconia et al., 2015; Martínez-Díaz and Hernández-Enrile, 2004). The local changes in horizontal stress directions have led to compression and uplift of Plio-Quaternary sediments offshore the Palomares Fault on the Iberian margin (Giaconia et al., 2015). In the Rif, field studies and paleomagnetic data demonstrated a $15^{\circ}$ counterclockwise rotation since the Upper Miocene (Crespo-Blanc et al., 2016, and references therein). At the present time, the direction of shortening seems to be orthogonal to the offshore NESW Trans-Alboran shear zone (TASZ) (Fig. 1) (Palano et al., 2013). Recent structural mapping has shown that the offshore distribution of the deformation in the Alboran Sea has localized during the Quaternary on a set of conjugated strike-slip faults: the Al-Idrissi Fault (AIF) and the Averroes Fault (Fig. 1) (Estrada et al., 2018; Galindo-Zaldivar et al., 2018; Lafosse et al., 2017; Martínez-García et al., 2013, 2017). Along the newly formed Averroes Fault (Fig. 1), the onset of the strike-slip motion has been estimated around $1 \mathrm{Ma}$ (Perea et al., 2018). Using a block rotation pinned model, Meghraoui and Pondrelli (2013) have proposed that the oblique convergence led to a rigid-block rotation accommodated by transcurrent faults (e.g., the TASZ, in Fig. 1). However, the timing and mechanism of this structural evolution remains poorly constrained.

In the present work, we address the Pliocene-Quaternary structural evolution of the southwestern margin of the Alboran Basin, toward the southern termination of the TransAlboran shear zone. In this poorly studied, yet key region, we analyze in high-resolution the changes in tectonic and stratigraphic setting by the means of newly acquired multiresolution 2D seismic reflection and TOPAS profiles and multibeam data. Based on the seismic stratigraphic interpretation of our database and on a regional synthesis of structural data, we propose that the structural evolution of the Alboran Basin and its southern margin reflects a Pleistocene change in tectonic style. Our new tectonic model explains the evolution of the southern margin of the Alboran Basin and the Al-Idrissi Fault zone during the constant Africa-Eurasia convergence.

\subsection{Geological and geodynamical settings}

The Alboran Basin developed over a collapsed Tertiary orogen and is limited onshore by the Betic-Rif belt (Fig. 1) (Comas et al., 1999). The formation of the Alboran Basin has been linked to Early Miocene forearc extension (BoothRea et al., 2007; Faccenna et al., 2001; Gómez de la Peña et al., 2018; Jolivet et al., 2008, 2009; Jolivet and Faccenna, 2000). Several Miocene strike-slip shear zones cut the entire basin from the Iberian to the Moroccan margins and accommodate the upper-plate deformation that forms a broad shear zone called the Trans-Alboran shear zone (TASZ; Fig. 1) (Leblanc and Olivier, 1984). Following the westward slab retreat, the TASZ acted as a left-lateral fault zone accommodating the extension of the Alboran Basin. The AfricaEurasia NW-SE oblique convergence led to a tectonic reorganization during the Late Miocene (Comas et al., 1999; Do Couto et al., 2016). Due to ongoing Africa-Eurasia convergence, the TASZ underwent an oblique positive inversion starting around $8 \mathrm{Ma}$ in the Sorbas Basin of the Betic margin (Do Couto et al., 2014; Martínez-García et al., 2017). The compression has migrated westward since approximately $7-$ $8 \mathrm{Ma}$ from the Spanish and Algerian margins to the Alboran Ridge and since ca. 5 Ma on the Al-Idrissi Fault (Figs. 1 and 2) (Giaconia et al., 2015).

In the southern margin of the Alboran Sea, the Alboran Ridge corresponds to a tectonic high that developed since the Late Miocene (Bourgois et al., 1992; Do Couto, 2014). The Alboran Ridge and the Yusuf Fault divide the Alboran Basin into three different subbasins: the West (WAB), South $(\mathrm{SAB})$ and East (EAB) Alboran Basin (Fig. 1). Conjugate to the Alboran Ridge, the right-lateral Yusuf Fault zone has been active since the Miocene (Fig. 1) (Martínez-García et al., 2013, 2017). The Al-Idrissi Fault divides the Alboran Ridge into the North (NAR) and South Alboran (SAR) ridges (Fig. 1). The SAR corresponds to a series of NE-SW striking submarine highs culminating around $-110 \mathrm{~m}$ (Xauen Bank, Petit Tofiño Bank, Tofiño Bank, Ramon Margalef High, Eurofleet High and Francesc Pagès Bank in Fig. 3).

Sedimentary processes, volcanism and tectonics shaped the morphology of the Alboran Ridge. Above the Messinian Erosional Surface (MES) (Estrada et al., 2011; GarciaCastellanos et al., 2011), the deep sedimentation in the Alboran Sea is driven by contouritic processes that has also shaped the seafloor since 5.33 Ma) (Ercilla et al., 2016; Juan et al., 2016). On both flanks of the Alboran Ridge, contourite deposits produce significant thickness variations in the Quaternary depositional units that are pinched and thinned to- 


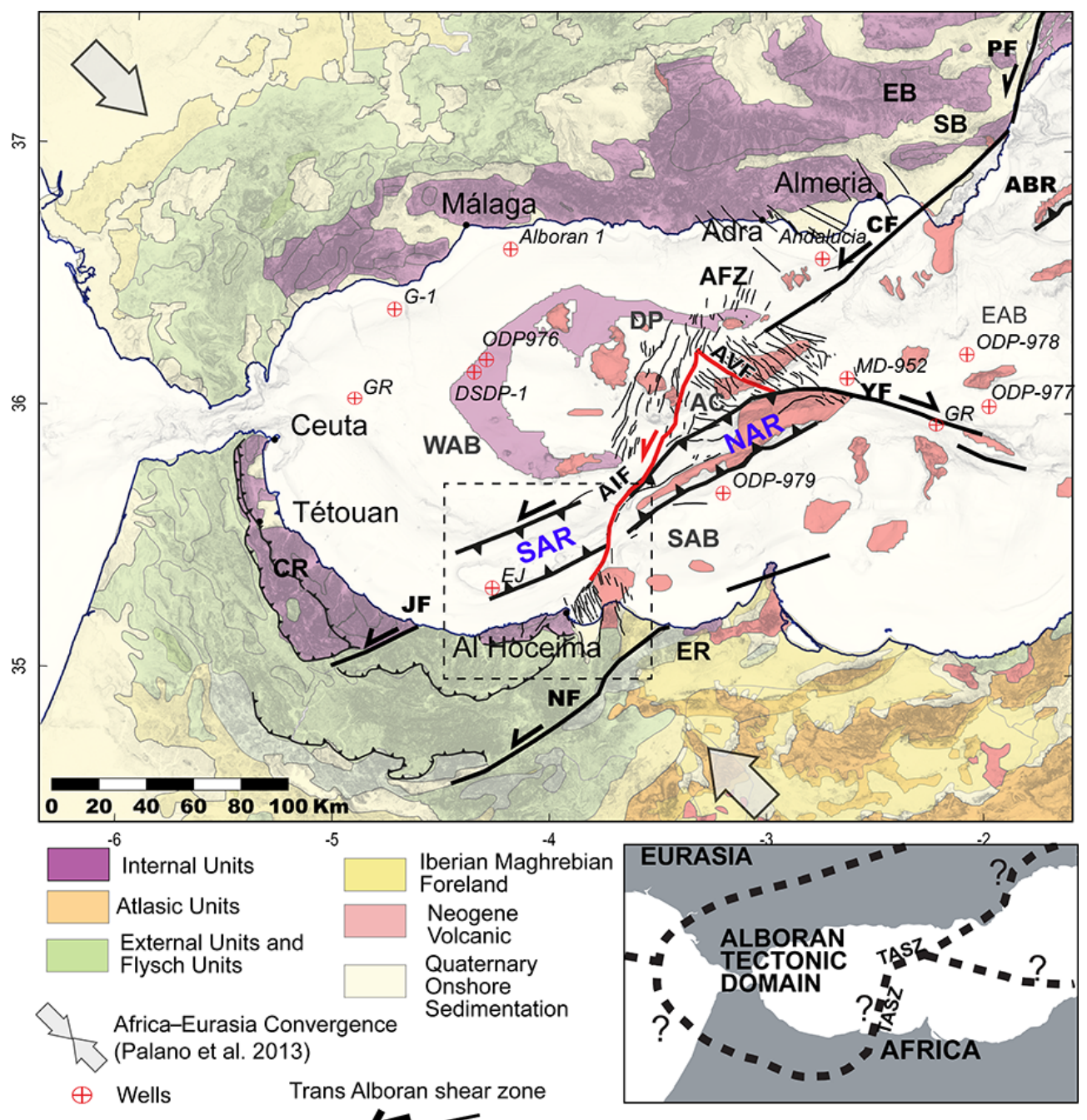

Figure 1. Topographic map and principal structural units of the Alboran region. Structural units in the studied area modified from Chalouan et al. (2008), Comas et al. (1999), Leblanc and Olivier (1984) and Romagny et al. (2014). The Trans-Alboran shear zone (TASZ) indicates the motion inferred for the Late Miocene - Pliocene period. The red faults are the present-day active Al-Idrissi Fault and its conjugated Averroes Fault. AC: Alboran Channel; AFZ: Adra Fault zone; AVR: Averroes Fault; ABR: Abubacer Ridge; CF: Carboneras Fault; CR: central Rif; DJ: Djibouti Plateau; EB: eastern Betic; EAB: East Alboran Basin; AIF: Al-Idrissi Fault; ER: eastern Rif; JF: Jebha Fault; NF: Nekor Fault; SAB: South Alboran Basin; SAR: South Alboran Ridge; SB: Sorbas Basin; NAR: North Alboran Ridge; YF: Yusuf Fault; and WAB: West Alboran Basin. Inset: hypotheses of plate boundaries between an Alboran tectonic domain and the African plate from Nocquet (2012).

ward the foot of the submarines highs (Juan et al., 2016). Submarine erosion can occur at the moat of the contouritic systems, generally at the foot of the slopes, whereas deposition occurs at deepest locations (Ercilla et al., 2016; Juan et al., 2016). The $70 \mathrm{~km}$ long SAR corresponds to a series of faults and folds and to volcanoes affecting the Pliocene-Quaternary depositional sequences (Fig. 3) (Bourgois et al., 1992; Chalouan et al., 1997; Gensous et al., 1986; Martínez-García et al., 2013; Muñoz et al., 2008; Tesson et al., 1987). To the south, the SAR flanks a NE-SW syncline called the South Alboran Trough and to the north, the Alboran Channel and the WAB (Fig. 3). The SAR marks the southward transition from thinned to thickened conti- nental crust (Díaz et al., 2016). It is an inherited Early Miocene extensional structure that has undergone compressive deformation since $8 \mathrm{Ma}$ (Fig. 1) (Do Couto et al., 2016). In the WAB, a syn-rift sequence is dated late AquitanianBurdigalian to Langhian (Do Couto et al., 2016). At the base of the sedimentary column of the SAR, the seismic reflection data show Early to mid-Miocene under-compacted shales deposited during the extensional period (Do Couto, 2014; Do Couto et al., 2016; Soto et al., 2008). Pre-Messinian deposits are exposed at the seafloor in the cores of the anticlines of the Alboran Ridge (Chalouan et al., 2008; Do Couto et al., 2016; Juan et al., 2016; Tesson et al., 1987). Local occurrences of volcanism in the Francesc Pagès Bank and the Ras Tarf 

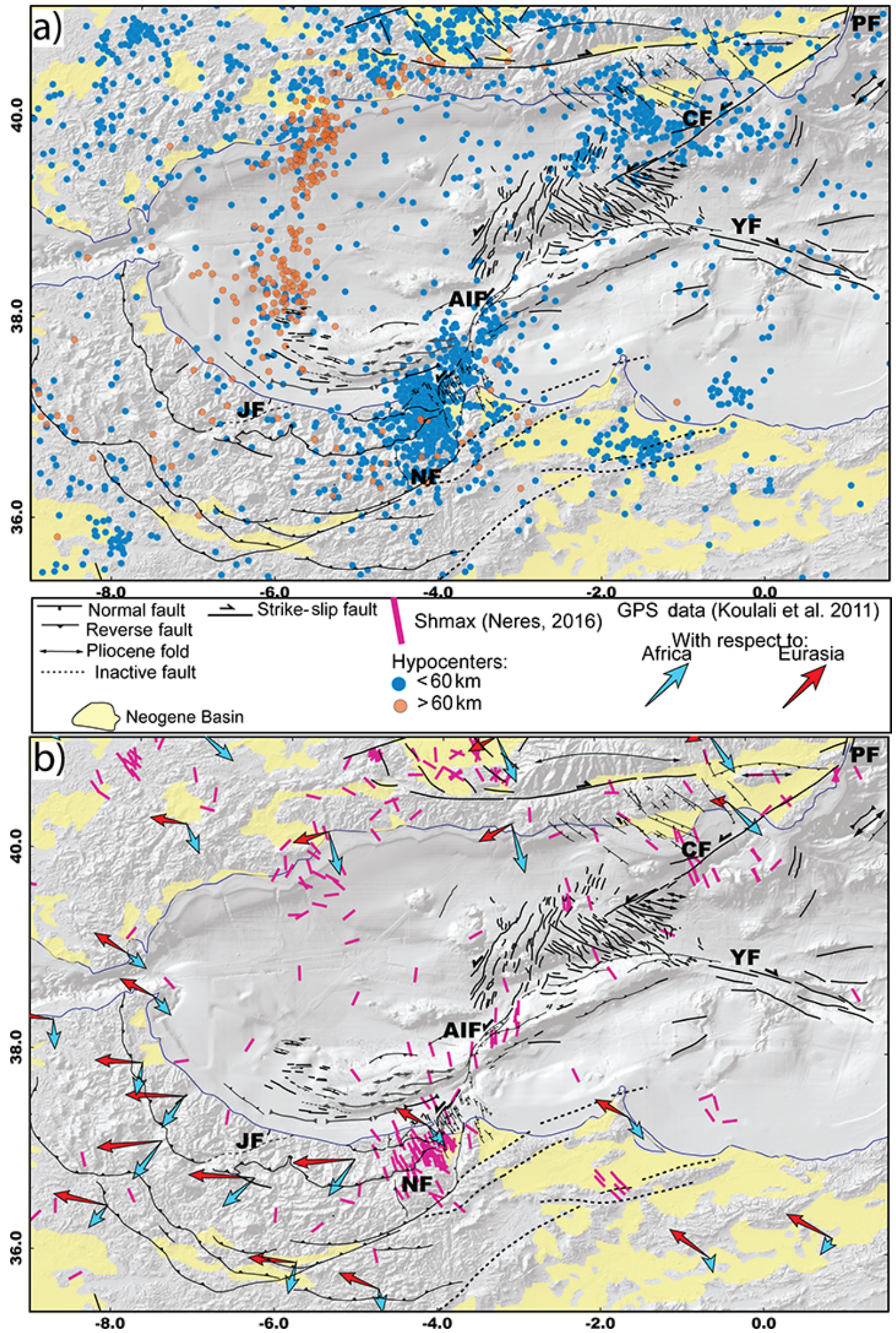

Figure 2. Maps showing the distribution of the seismicity along the Neogene tectonic structures in the Alboran Sea. (a) Neotectonic map of the Alboran region modified from d'Acremont et al. (2014), Alvarez-Marrón et al. (1999), Chalouan et al. (1997), Estrada et al. (2014), Gràcia et al. (2006, 2012), Lafosse et al. (2017), Martínez-García et al. (2011), Muñoz et al. (2008), Perea et al. (2014), Vázquez et al. (2014) and this study. Seismicity from IGN catalogue 1970-2017 (http://www.ign.es/, last access: 1 June 2018); only earthquakes with $M_{\mathrm{W}} \geq 3$ and depth $\geq 2 \mathrm{~km}$ are figured. (b) GPS data from Koulali et al. (2011) and $\mathrm{Sh}_{\max }$ from Neres et al. (2016). See Fig. 1 for scale. CF: Carboneras Fault; PF: Palomares Fault; YF: Yusuf Fault; NF: Nekor Fault; and AIF: Al-Idrissi Fault zone. 


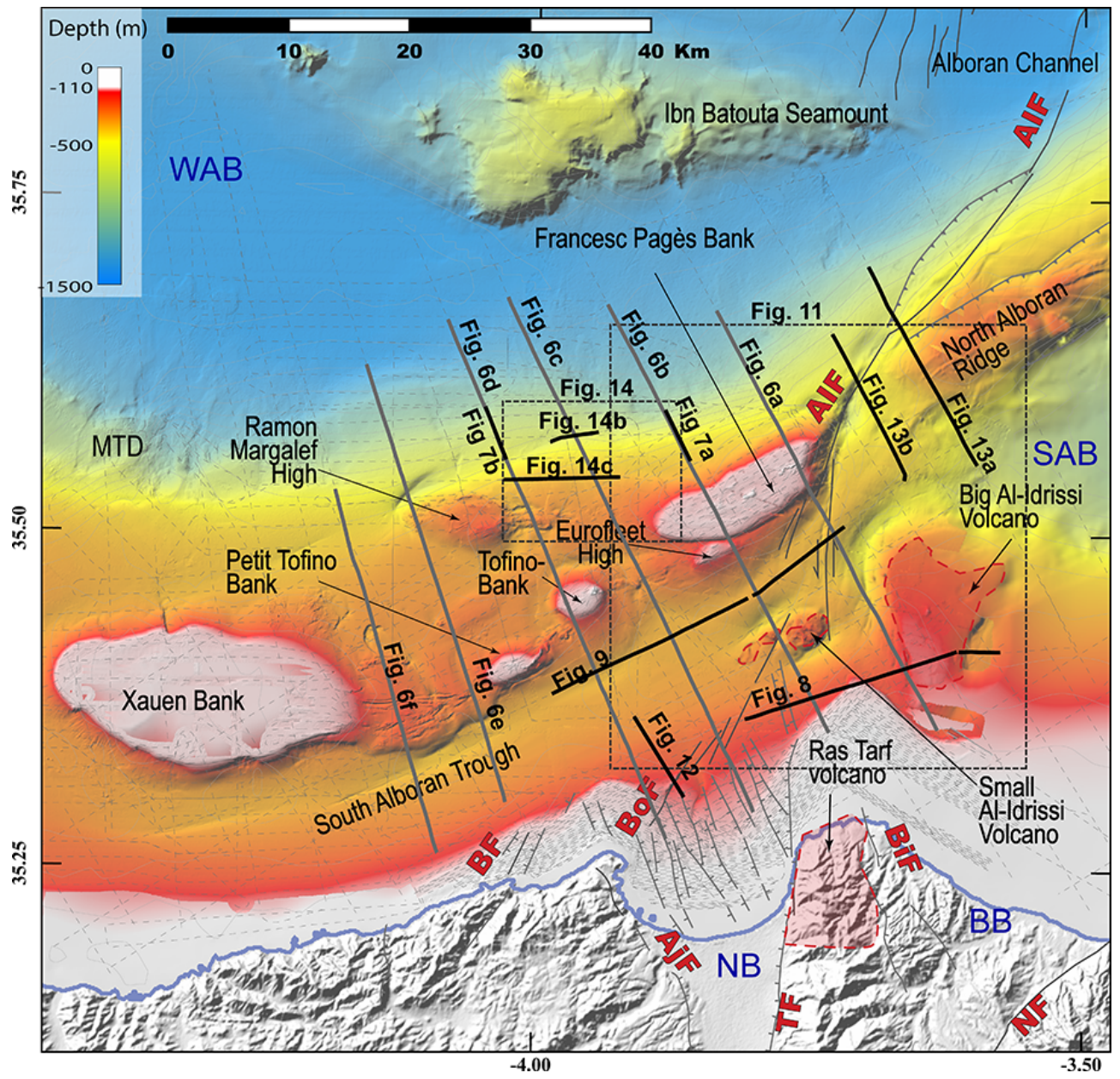

Figure 3. Bathymetry of the studied area showing the main morpho-structural features of the studied area. Dark grey and black lines: positions of the seismic lines used in the study. MTDs: mass transport deposits; WAB: West Alboran Basin; SAB: South Alboran Basin; BB: Boudinar Basin; BF: Boussekkour Fault; Bof: Bokoya Fault; BiF: Boudinar Fault; NB: Nekor Basin; NF: Nekor Fault; AIF: Al-Idrissi Fault zone; TF: Trougout Fault; and AjF:Adjir-Imzouren Fault.

are of Miocene and Pliocene age (Figs. 1 and 3). The volcanism in the Francesc Pagès Bank is not accurately dated (Gill et al., 2004). Basaltic rocks are dated between 9.6 and 8.7 Ma in the same area by Duggen et al. (2004). In the Ras Tarf (Fig. 3), the volcanism ends around $9 \mathrm{Ma}$ (El Azzouzi et al., 2014). Samples of the Ibn Batouta Seamount contain 5 Ma old gabbro (Duggen et al., 2008).

Since the Late Miocene, deformation has migrated from the eastern Betic margin toward the SAR in the southwest (Fig. 1) Giaconia et al. (2015). The SAR has been inverted during the Plio-Quaternary along NE-SW trending faults (Fig. 1) (Chalouan et al., 1997). Seismic reflection profiles and well data show that the folding continued until the Quaternary in the Francesc Pagès Bank and highlight several erosion periods during Pliocene-Quaternary time (GalindoZaldivar et al., 2018; Tesson et al., 1987). Unconformities and increasing accumulation rates indicate three tectonic phases: phase 1 dated from 5.33 to $4.57 \mathrm{Ma}$, phase 2 from
3.28 to $2.45 \mathrm{Ma}$ and phase 3 between 1.81 and $1.19 \mathrm{Ma}$ (Martínez-García et al., 2013). More recently, MartínezGarcía et al. (2017) suggested that the uplift along the Alboran Ridge culminated around $2.45 \mathrm{Ma}$ in response to shortening.

The most recent deformation involves NNW-SSE sinistral transtension from the frontal indentation of the northern part of the Alboran Ridge to the transtensive Nekor Basin via the AIF, across the NAR and the SAR at the NE tip of the Francesc Pagès Bank (Dillon et al., 1980; Estrada et al., 2018; Lafosse et al., 2017). The Nekor Basin accommodates the present-day deformation of the southern Alboran margin (Figs. 2 and 3). Bathymetric and seismic reflection data show that the deformation along the AIF is accommodated by a series of sinistral NNE-SSW strike-slip faults segments (Figs. 1 and 2) (Ballesteros et al., 2008; Martínez-García et al., 2011). The AIF propagated southward during the Quaternary (Ballesteros et al., 2008; Grà- 
cia et al., 2006; Martínez-García et al., 2011, 2013), connecting to the NNE-SSW active strike-slip BoussekkourBokoya Fault zone (Fig. 3) (d'Acremont et al., 2014; Calvert et al., 1997; Lafosse et al., 2017).

East of the TASZ, the SAB and the Oriental External Rif behave as the African block (Koulali et al., 2011; Vernant et al., 2010). GPS kinematics show a WNW-ESE convergence rate of $4.6 \mathrm{~mm} \mathrm{yr}^{-1}$ between the Africa and Eurasia plates (Nocquet and Calais, 2004). Maximum present-day extrusion rates of $5.5-6 \mathrm{~mm} \mathrm{yr}^{-1}$ in the Alboran tectonic domain are measured between the Jebha and Nekor faults and indicate a southwestward lateral escape (Fig. 2b) (Koulali et al., 2011; Vernant et al., 2010).

The Nekor Basin, SAR and AIF are affected by significant crustal seismicity (Bezzeghoud and Buforn, 1999; Stich et al., 2005). The focal mechanisms of three main regional earthquakes show subvertical nodal planes and a left-lateral displacement (Fig. 4) (Bezzeghoud and Buforn, 1999; Biggs et al., 2006; Calvert et al., 1997; El Alami et al., 1998; Hatzfeld et al., 1993; Stich et al., 2005, 2006). At the northern border of the Nekor Basin, earthquakes with $M_{\mathrm{w}}=6.3$ and 5.9 occurred in 1994 and 2004, respectively (Fig. 4) (Custódio et al., 2016). The NNE-SSW fault tracks identified at the seafloor, in the vicinity of the epicenters, can correspond to the active fault planes deduced from seismological data (d'Acremont et al., 2014; Calvert et al., 1997; Lafosse et al., 2017). On 25 January 2016, a $M_{\mathrm{w}}=6.3$ earthquake occurred in the vicinity of the AIF (Buforn et al., 2017; Medina and Cherkaoui, 2017; Galindo-Zaldivar et al., 2018). In the deep basin, the earthquake sequence indicates a strike-slip mode of the AIF, with mainly NNE-SSW left-lateral motion (Ballesteros et al., 2008; Buforn et al., 2017; GalindoZaldivar et al., 2018; Martínez-García et al., 2011; Medina and Cherkaoui, 2017). Several compressional events with NE-SW nodal planes parallel to the Alboran Ridge indicate that the Alboran Ridge is locally reactivated (Fig. 4). In the Nekor Basin, the deformation is partitioned into a normal component in the center of the basin and a left-lateral component on its borders (Fig. 4) (Lafosse et al., 2017). In the SAR, the style of the deformation is unclear, with focal mechanisms showing strike-slip or normal components indiscriminately (Stich et al., 2010). Below the WAB, deep earthquakes occur at depths $>60 \mathrm{~km}$ (Fig. 2a) and are associated with the ongoing necking of sinking lithospheric material (Fig. 2a) (Bezada et al., 2013; Ruiz-Constán et al., 2011; Sun and Bezada, 2020; Thurner et al., 2014). This distributed lithospheric tear could have propagate from the Betic to the WAB (Heit et al., 2017; Mancilla et al., 2015), yet the timing and the effect of this tear on the local tectonic is still poorly understood.

\section{Material and methods}

The data used in this study consist of multichannel seismic, sparker and TOPAS profiles and multibeam bathymetry, acquired during four oceanographic surveys (Fig. 3). The seismic reflection data were acquired with a 12-channel streamer during the 2011 Marlboro-1 survey, as eight NNW-SSE parallel lines crossing the W-E folds of the SAR and two WSWENE parallel lines in the southern domain (Fig. 3). The 2012 SARAS survey focused on the acquisition of shallow data, SPARKER and TOPAS profiles, multibeam bathymetry, and acoustic reflectivity at a $25 \mathrm{~m}$ per pixel resolution of the deep submarine seafloor (Rodriguez et al., 2017). During the Marlboro-2 survey in 2012 (d'Acremont et al., 2014; Lafosse et al., 2017), SPARKER profiles and shallow multibeam bathymetry at a $5 \mathrm{~m}$ per pixel resolution were acquired. The bathymetric data from the 2016 INCRISIS survey were also used (Galindo-Zaldivar et al., 2018). In addition, we used a digital elevation model downloaded from the EMODNET data set (http://www.emodnet.eu/, last access: 1 June 2018) to fill the missing parts of our dataset.

We used the seismic reflection and TOPAS data interpretation for the tectonic analysis of the subsurface. At the seafloor, we made a visual recognition of fault scarps using the multibeam bathymetry and the curvature maps. The curvature is known as a relevant parameter to track the fault offsets on 3D seismic section (e.g., Roberts, 2001) and at the seafloor (e.g., Paulatto et al., 2014). The sum of the plan-curvature values was made with the help of ArcGis V10.2 using the focal statistics tool to smoothen the noise at depths below $-150 \mathrm{~m}$. The seismic-stratigraphic analysis of the Pliocene-Quaternary sequences is based on the stratigraphy defined by Juan et al. (2016) (Fig. 5). The chronology of the seismic stratigraphic boundaries was defined based on age calibration of data from scientific wells DSDP 121 and ODP 976, 977, 978 and 979 (Figs. 1 and 5) (Ercilla et al., 2016; Juan et al., 2016). Using the velocity analysis for the ODP well 976 (Soto et al., 2012), we assume an average P-wave velocity of $1750 \mathrm{~m} \mathrm{~s}^{-1}$ for the Pliocene-Quaternary pelagic sediments. We propose seismic and sequential stratigraphy interpretations of depositional units based on the nomenclature and general principles presented in the literature (Catuneanu, 2007; Catuneanu et al., 2011). All seismic lines shown in the present article are presented uninterpreted in the supplementary material (Figs. S1 to S8 in the Supplement).

\section{Results}

\subsection{Pliocene-Quaternary seismic stratigraphy}

The Pliocene-Quaternary sedimentary sequence of the southern Alboran margin has been divided into three Pliocene (Pl1, Pl2 and Pl3) and four Quaternary (Qt1 to 


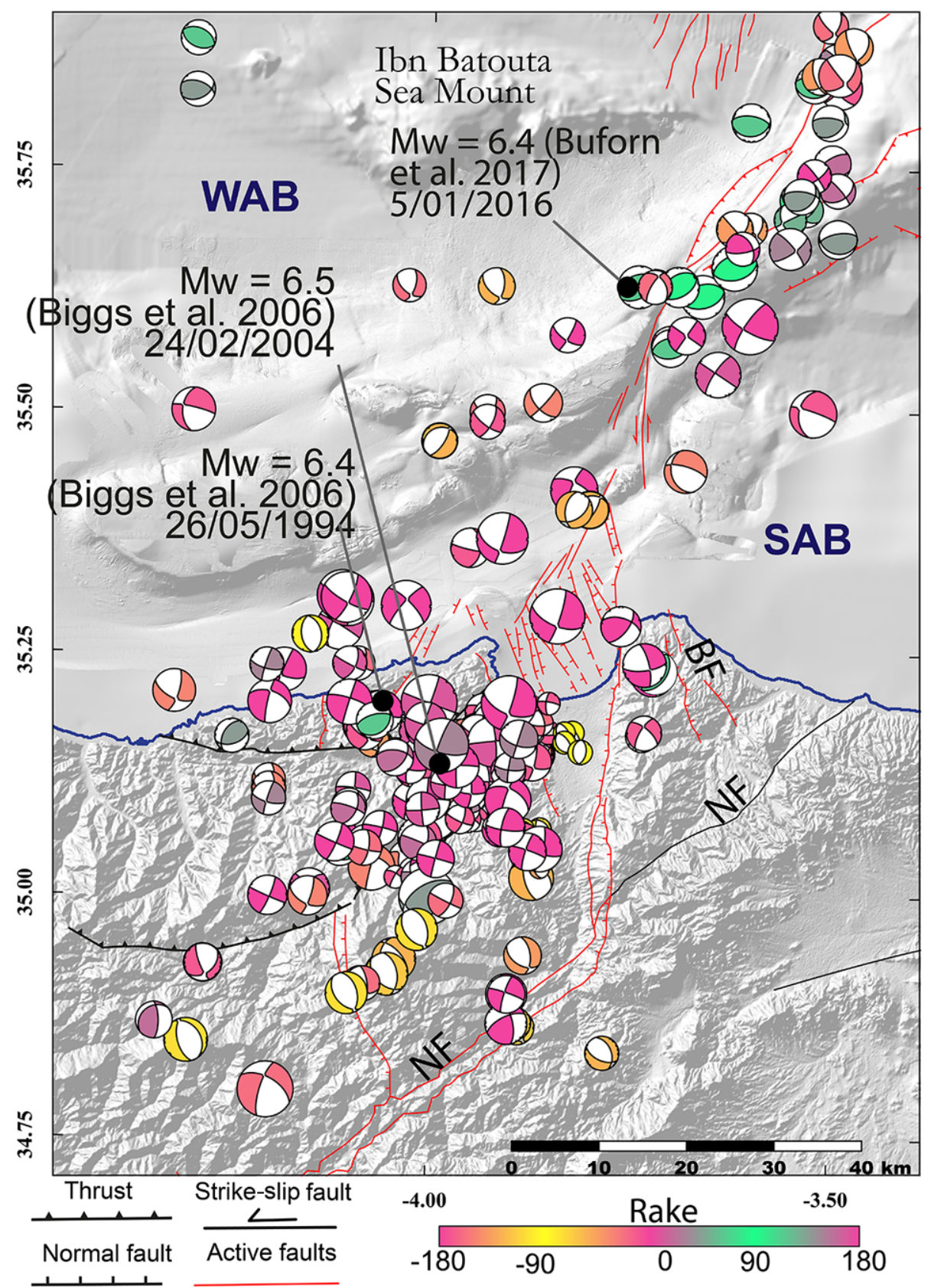

Figure 4. Map of the distribution of the present-day deformation showing strike-slip and compressive deformation along the northern part of the studied area and extensional and strike-slip structures along the southern part. Focal mechanism till 2014 period from the compilation of Custódio et al. (2016) and for the year 2016 from GCMT project (http://www.globalcmt.org/, last access: 1 June 2018, Dziewonski et al., 1981 and Ekström et al., 2012). The size of the focal mechanisms corresponds to the magnitude values (from $M_{\mathrm{W}}=2.3$ to 6.4 ). Structural data compiled from Ballesteros et al. (2008), Biggs et al. (2006), Buforn et al. (2017), Chalouan et al. (1997), Lafosse et al. (2017) and Martínez-García et al. (2011). BF: Boudinar Fault; WAB: West Alboran Basin; SAB: South Alboran Basin; and NF: Nekor Fault.

Qt4) seismic units (Fig. 5). These units are limited at the base by discontinuity surfaces, with $\mathrm{M}, \mathrm{P} 0$ and $\mathrm{P} 1$ for the Pliocene units and BQD and Q0 to Q2 for the Quaternary units. These discontinuity surfaces are mostly defined by onlap and erosive surfaces; locally, downlap surfaces are identified (Figs. 6 and 7). Subparallel, parallel, oblique and wavy stratified reflections characterize the Pliocene units. Pl1, Pl2 and $\mathrm{Pl} 3$ units are pinching toward the structural highs and show aggrading wedge geometries. The Quaternary seismic units (QT1 to QT4) show an aggradational geometry and pinch on the older tilted Pliocene deposits (Figs. 6 and 7) (Juan et al., 2016). 


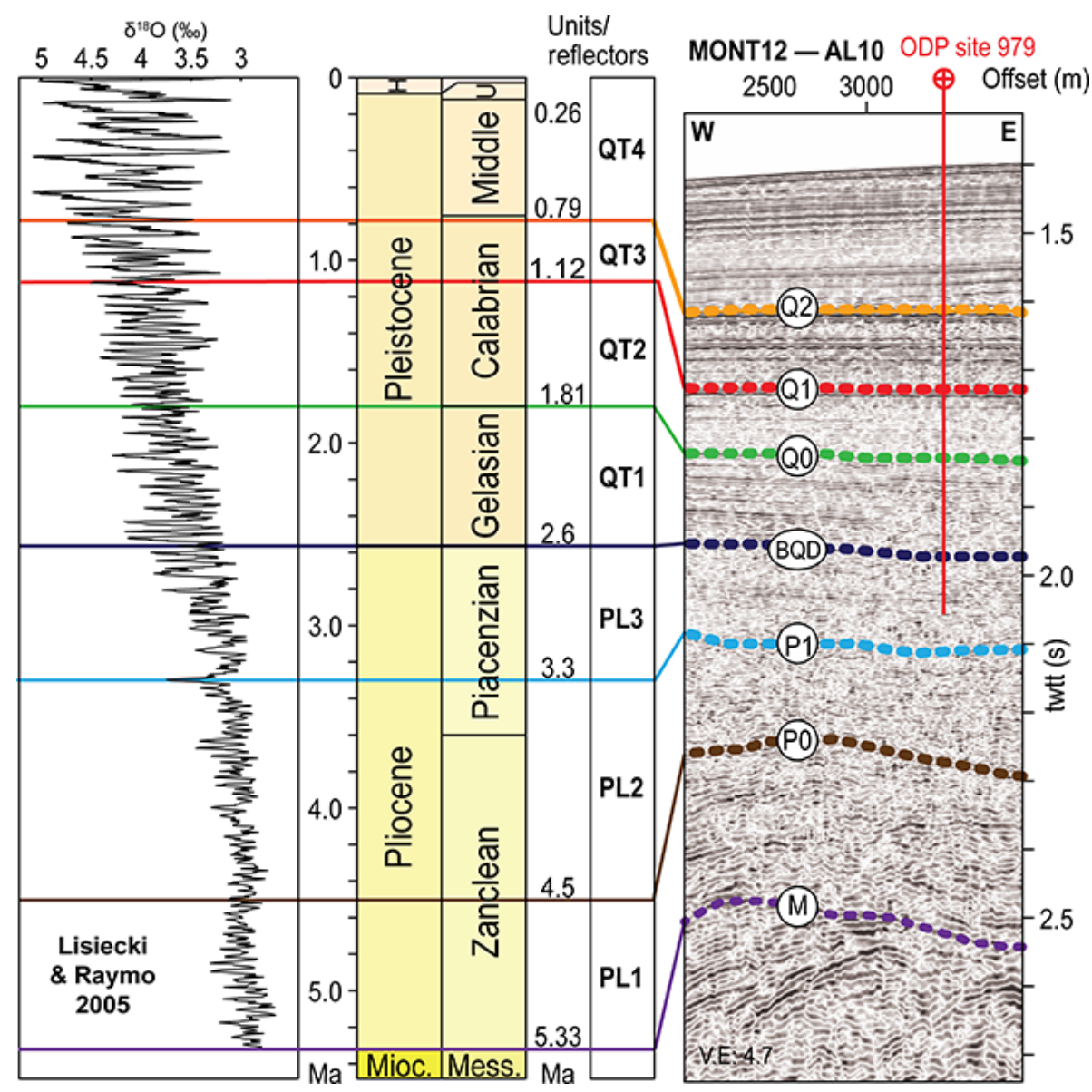

Figure 5. Well log correlation to the seismic section, seismic line crossing the location of the ODP 979 site, vertical stacking of the Pliocene and Quaternary units, and available $\delta^{18} \mathrm{O}$ curve from Lisiecki and Raymo (2005). The colors of the stratigraphic surfaces are the same as in the following seismic lines.

Contouritic deposits and associated sedimentary features, mass transport deposits (MTDs) and volcanic deposits constitute the Pliocene-Quaternary deposits. The plastered drift type is dominant and contributes to cover the structural highs (Juan et al., 2016). Truncations at the foot of topographic highs corresponds to contourite moats and channels on seismic lines (Fig. 7). Sediments show local intercalations of lenticular chaotic or transparent facies that are interpreted as mass-flow deposits, corresponding to scars on the bathymetry (Fig. 3) (Rodriguez et al., 2017). Regarding the volcanic deposits, two buried volcanic edifices are identified on seismic reflection, the Big Al-Idrissi Volcano (Figs. 3 and 8) and the Small Al-Idrissi Volcano (Figs. 3, 6 and 9). Acoustically, they correspond to a seismic facies of poorly continuous, high-amplitude reflectors (Figs. 6, 8 and 9). Pliocene to Quaternary reflectors onlaps onto these seismic bodies (Figs. 8 and 9). They trend NE-SW following the trend of South Alboran Trough (Fig. 10).

The Big Al-Idrissi Volcano corresponds to a conic structure located to the north of the Ras Tarf (Figs. 3 and 8) that has been interpreted as an $\mathrm{N}-\mathrm{S}$ volcanic ridge (Bourgois et al., 1992). The top of this seismic body merges with the $M$ reflector (Fig. 8). Above, Pliocene-Quaternary seismic units bury this volcano and show prograding to aggrading sigmoid reflectors that characterize the growth of a continental shelf (Fig. 8). On the west side of this seamount, the trajectory of the offlap breaks is concave up, indicating that the rate of progradation decreases progressively with time. Reflectors onlap on the bottomsets and foresets of the prograding seismic units, marking the beginning of a retrogradation after $1.81 \mathrm{Ma}$ (Fig. 8). West-dipping normal faults offset the depositional unit of prograding sigmoid reflectors (Fig. 8). These normal faults correspond to scarps at the seafloor (Figs. 8 and 11). Toward the top of the sequence, a unit of flat-lying reflectors corresponds to the bottomsets of the Late Pleistocene Moroccan shelf offshore of the Ras Tarf (Fig. 8). The flat top of the Big Al-Idrissi Volcano culminates at an approximate depth of 150-200 m below the present-day sea level and corresponds to a toplap surface (Fig. 8). 

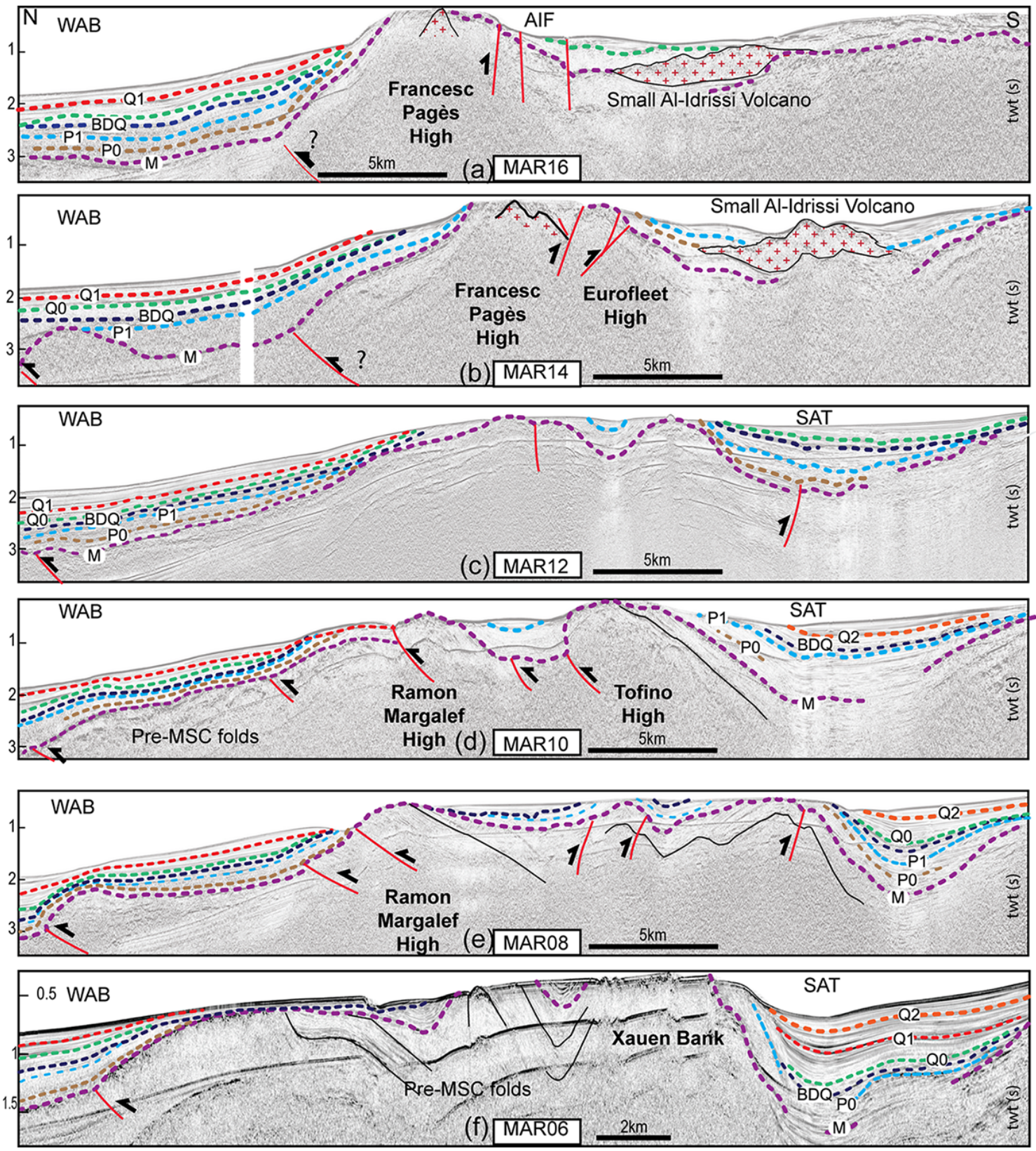

Figure 6. Multichannel seismic lines showing the Plio-Quaternary stratigraphy and structural features. Dashed and colored lines are the stratigraphic surface defined in Fig. 5. Black reflectors, pre-MSC reflectors. The seismic section (a-f) are ordered from east to west. WAB, South Alboran Basin; SAT, South Alboran Trough; AIF, Al-Idrissi Fault zone.

In the South Alboran Trough, the Small Al-Idrissi Volcano has a $4-5 \mathrm{~km}$ wide conic structure and trends roughly NNE-SSW (Figs. 9, 10 and 11). This seismic body intercalated within the Pl1 seismic unit pinches abruptly toward the west (Fig. 9). This body corresponds to a rounded high at the seafloor (Fig. 11). The top of the Pl1 seismic unit rests unconformably on this seismic body indicating an Early Pliocene age (Fig. 9). In the Francesc Pagès Bank, a seismic body with similar facies is present at the core of an NNE-SSW striking anticline (Fig. 6), truncated by the $\mathrm{M}$ reflector (Fig. 6).
North of the Nekor Basin, the shelf records an Early Quaternary regression (Fig. 12). We follow the Q1 surface northeastward toward the top of the submerged shelf surrounding the Big Al-Idrissi Volcano (Fig. 8). The Q0 reflector corresponds to an unconformity at the bottom of prograding oblique reflectors. This depositional unit displays the geometry of continental shelf deposits. The most distal offlap break shows the maximum extent of the Pleistocene continental shelf north of the Nekor Basin. It indicates that the retrogradation of the shoreline starts before $1.12 \mathrm{Ma}$ and af- 

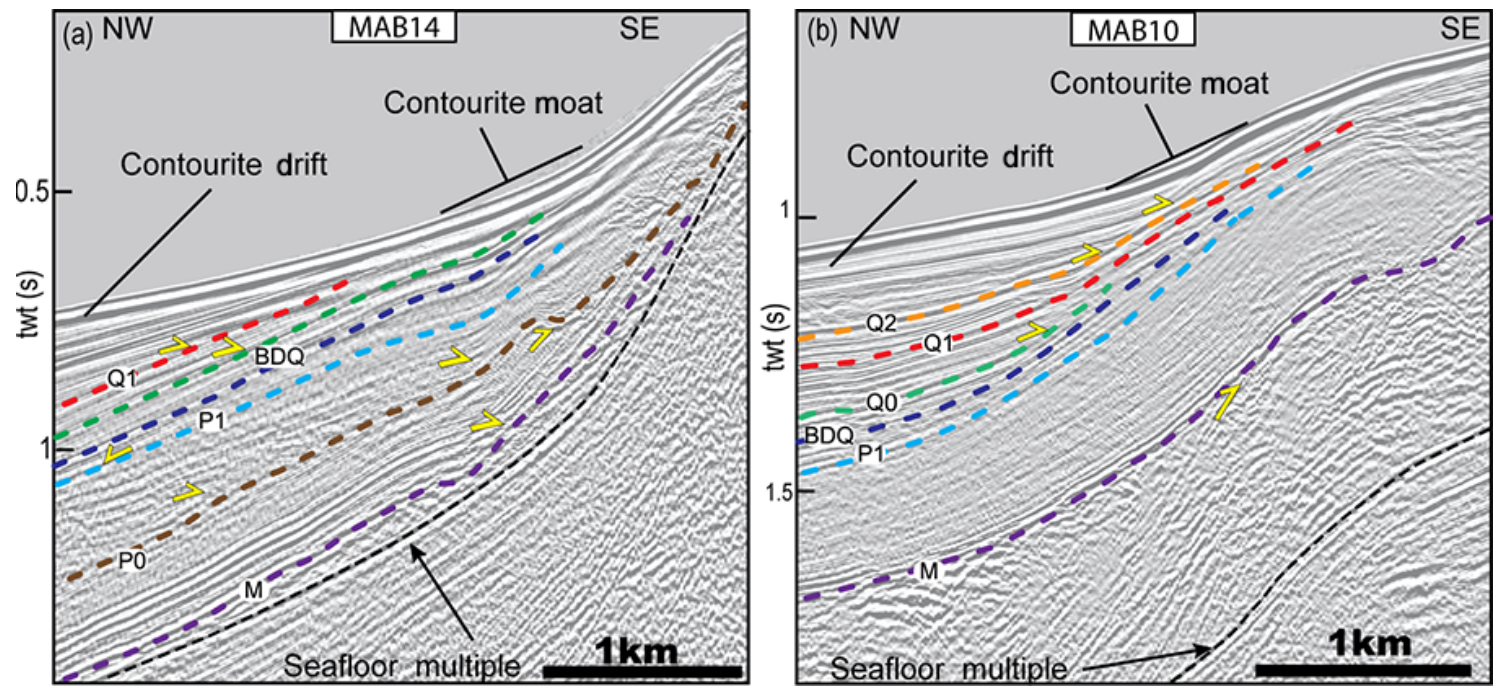

Figure 7. Seismic unconformities at the foot slope of the northern flank of the South Alboran Ridge. (a) Seismic line at the foot of the Francesc Pagès Bank. (b) Seismic line at the foot of the Ramon Margalef High. The seismic lines show the diachronism of the deformation affecting the SAR during the Pliocene. After 2.6 Ma, the moats of the contourites pinch at the feet of the folds.
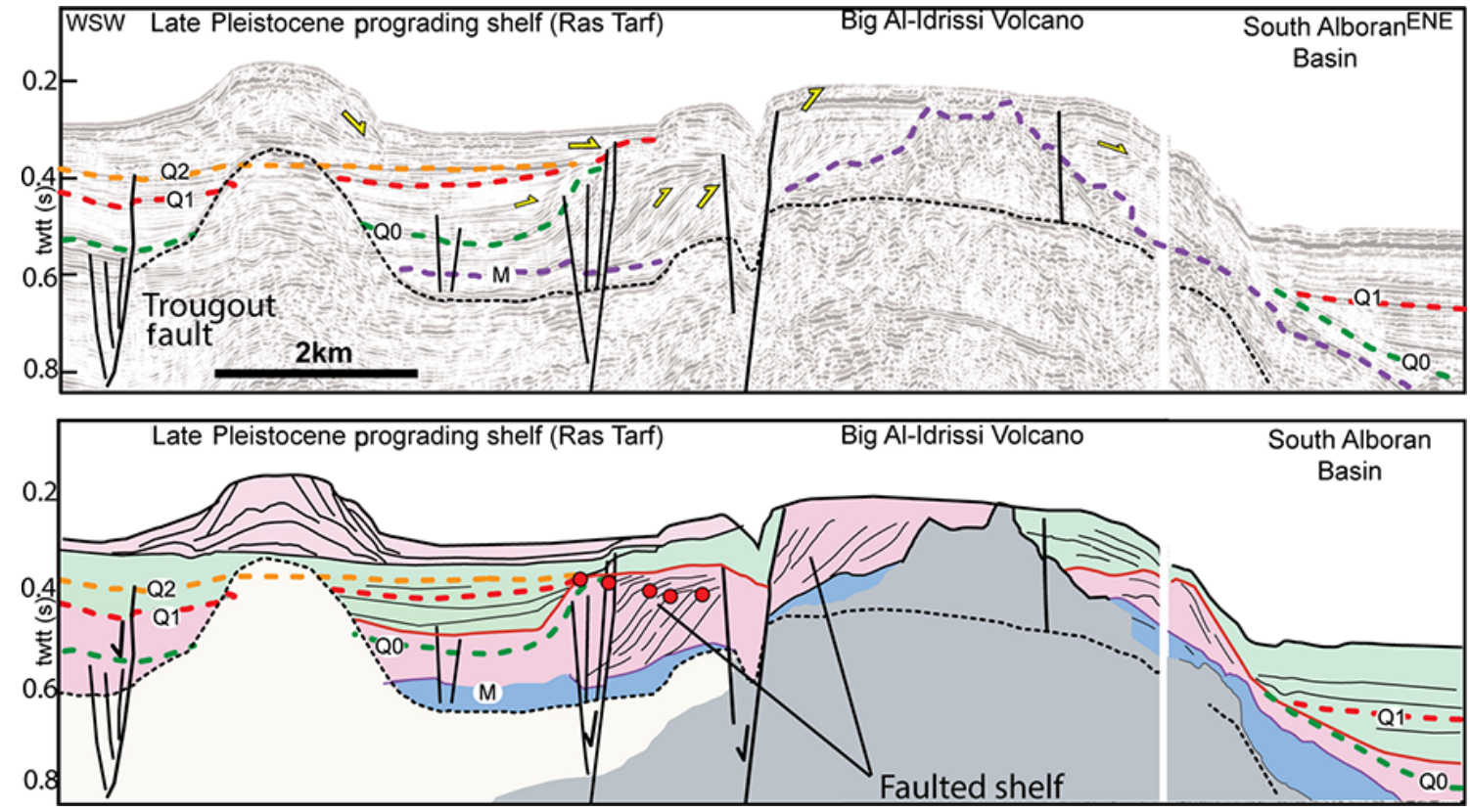

Figure 8. Multichannel seismic profile showing the transgression of marine sediment (in green) over the prograding shelf to the edges of the Big Al-Idrissi Volcano (in pink) crossing the Ras Tarf promontory and the Big Al-Idrissi Volcano. Dashed black reflector: multiple of the seafloor. Red points: offlap break (paleoshoreline) marking the concave up trajectories of the offlap breaks and progradation of the shelf and the first transgression before 1.81 Ma. The red surface is a maximum regressive surface in the sense of Catuneanu et al. (2011). The seismic line shows the transgression of marine sediment (in green) over the Pliocene to Quaternary prograding shelf to the edges of the Big Al-Idrissi Volcano (in pink). Older depositional units are colored in blue, and the acoustic basement is in grey.

ter 1.81 Ma (Q1 reflector, Fig. 12). The most distal offlap break near Al Hoceima is located around $312 \pm 30 \mathrm{mstwt}$ (milliseconds two-way travel time), corresponding to a depth of $188 \pm 5 \mathrm{~m}$ below sea level (Fig. 12). In the distal part of the shelf, we interpret a seismic body of poorly continuous wavy reflectors deposited above an erosional surface as a local mass transport complex, which could mark an earlyQuaternary destabilization of the shelf. 


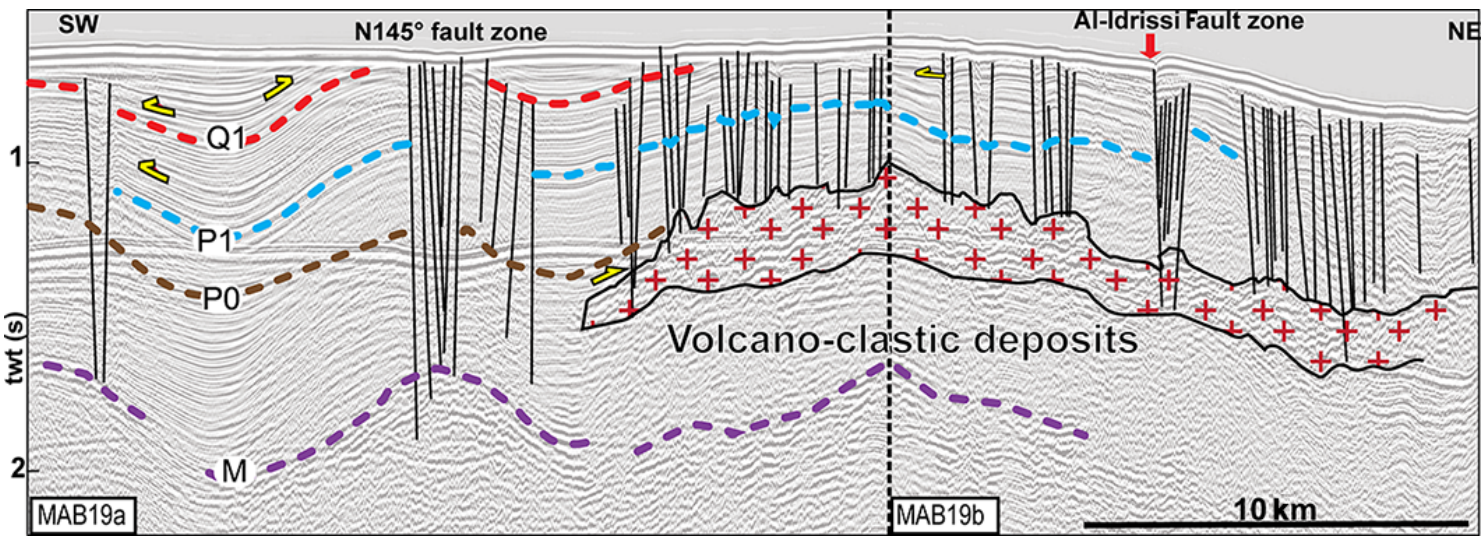

Figure 9. Multichannel seismic profile showing seismic stratigraphy and the main structural elements along a portion of the South Alboran Trough located between $\mathrm{N} 145^{\circ}$ striking faults and the AIF. Line track on Fig. 3. (a) Raw seismic line. (b) Interpreted seismic line. Red crosses in (b) represent a seismic body made of poorly continuous high-amplitude reflectors interpreted as volcano-clastic deposits.

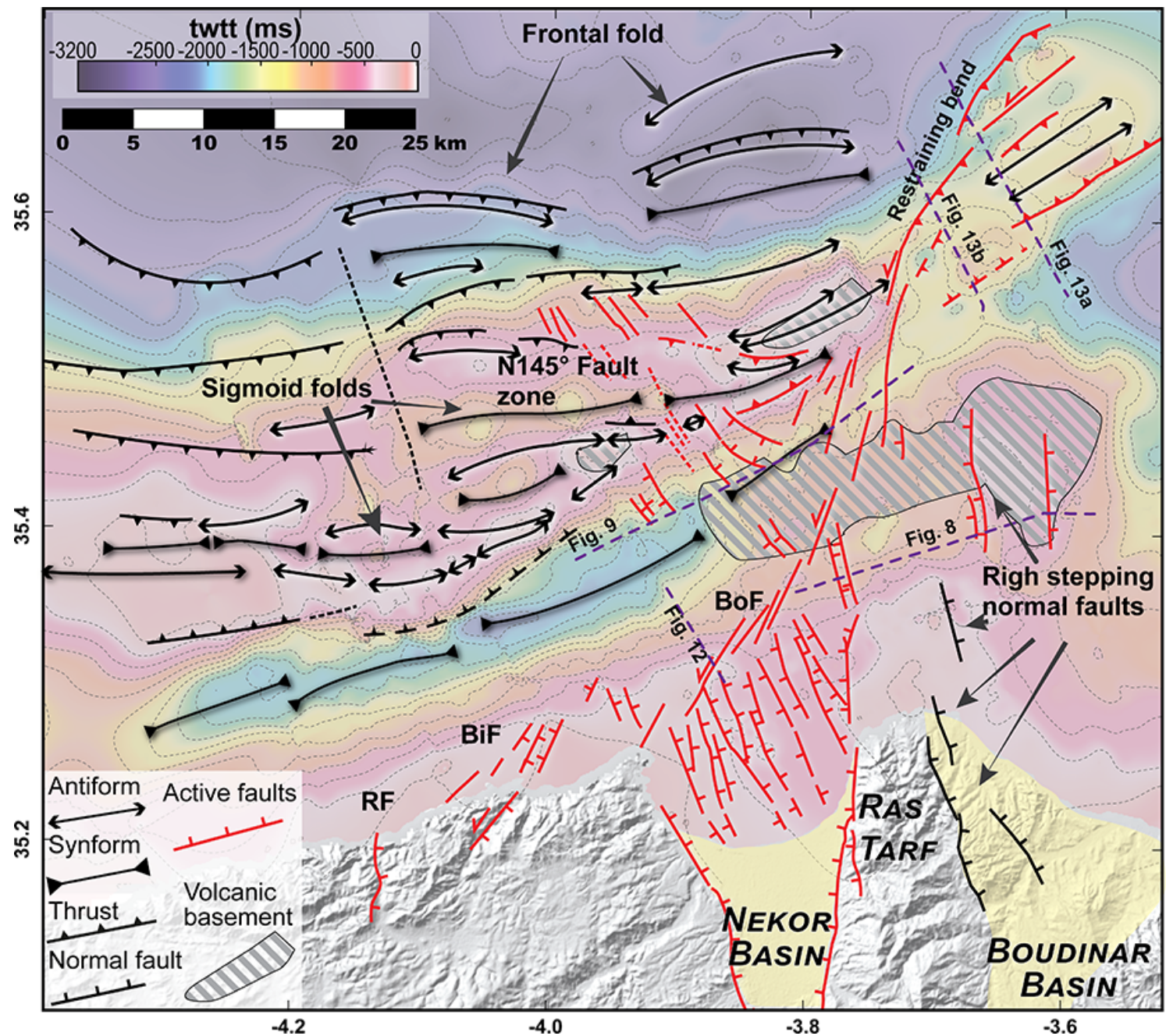

Figure 10. Structural map of Plio-Quaternary faults and folds overlying the map of depths of the Messinian unconformity. Active faults correspond to the faults affecting the seafloor. BF: Boussekkour Fault; Bof: Bokoya Fault; and RF: Rouadi Fault. The two-way travel time (twtt) is in millimeters per second. 

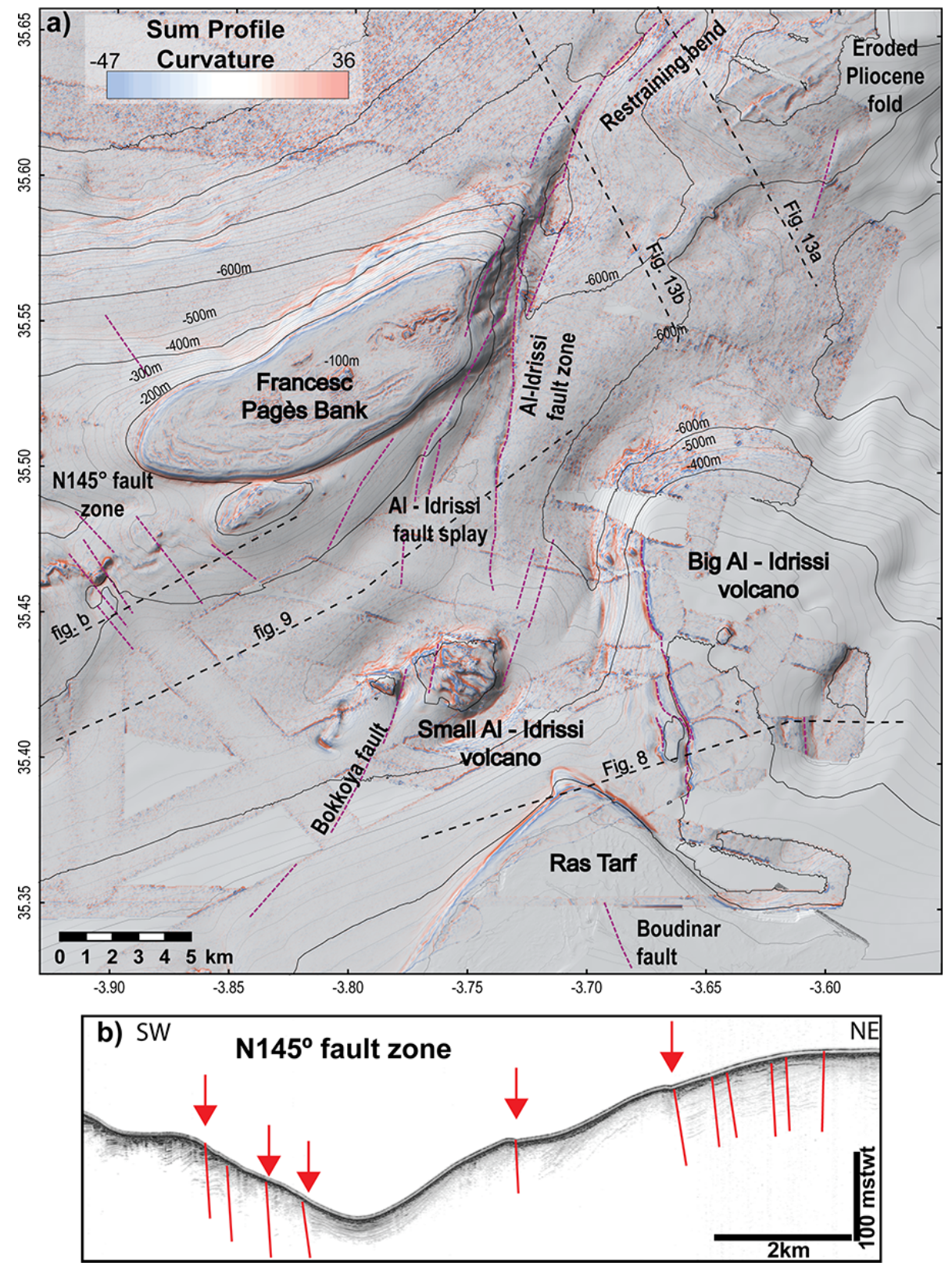

Figure 11. Active structures around the roughly NNE-SSW AIF and adjacent submarine highs. The AIF bends to the north, where it follows the trends of the NAR. High values of curvatures in the Francesc Pagès Bank and the northeast corner of the map underline the linear features at the seafloor, which corresponds to the truncated Miocene-Pliocene layers. Extreme positive values in red represent concave topography at the seafloor; extreme negative values in blue represent convex topography. (a) Profile curvature map textured above the shaded bathymetry; dashed purple lines: fault tracks at the seafloor; dashed black lines: positions of the seismic line in (b) and in Figs. 8, 9 and 13. (b) TOPAS profile showing active $\mathrm{N} 145^{\circ}$ normal faults. Red lines: active faults; red arrows: positions of the fault traces in (a).

\subsection{Tectonic structures}

\subsubsection{Folded structures in the South Alboran Ridge (SAR)}

The shortening in the SAR is distributed from east to west over a 10 to $25 \mathrm{~km}$ wide folding structure, composed of series of two to four $4 \mathrm{~km}$ wavelength anticlines (Figs. 6 and 10).
Northward-verging anticlines characterize the northern deformation front (Fig. 6). In the eastern part of the SAR, the Francesc Pagès and the Eurofleet highs correspond to a south-verging $10 \mathrm{~km}$ wide antiformal stack of pinched anticlines (MAB16 and 14; Fig. 6). Several southward and northward dipping blind thrusts affect the $\mathrm{M}$ reflector (Fig. 6). From east to west and above the thrust faults, a series of anti- 

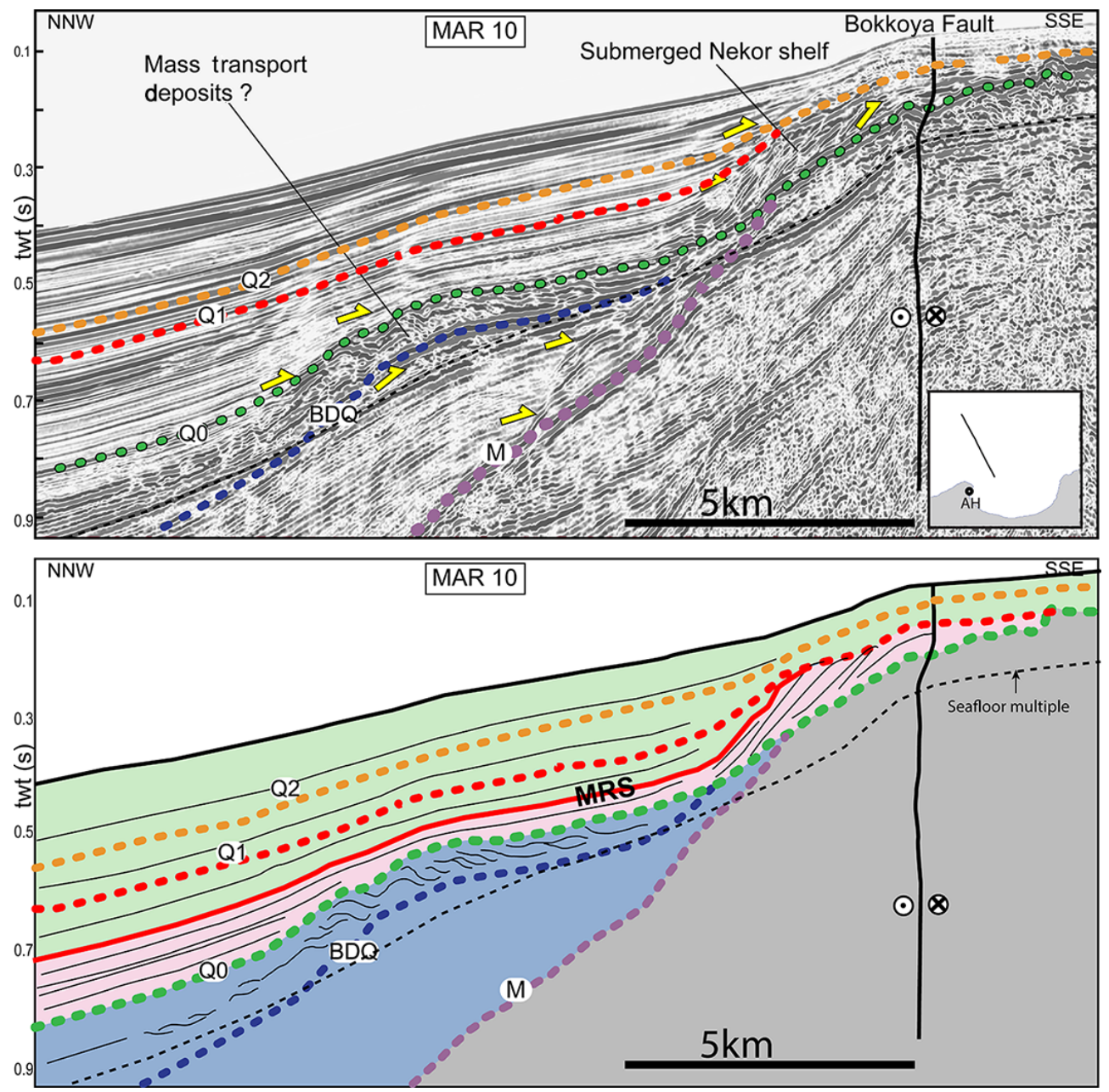

Figure 12. SPARKER seismic line showing the transgression of marine sediment (in green) over the prograding shelf of the Nekor Basin (in pink). Oldest depositional units (Pliocene) are colored in blue, and the acoustic basement is in grey. The Maximum Regressive Surface (MRS) is in red.

clines and synclines draw a sigmoidal pattern (Fig. 10). Azimuths of the hinge lines trend toward a mean $\mathrm{N}^{\circ} 5^{\circ}$ direction at the center of the folds and toward a $\mathrm{N} 070^{\circ}$ direction toward the tips of the folds. The orientation of the most western tip of the SAR changes from NE-SW to E-W (Fig. 6). The azimuths of the Pliocene folds in the southern termination of the NAR trend N058 (Fig. 10).

Below the $M$ surface, truncated Miocene seismic units show local folding (Fig. 6f). Along the northern flank of the SAR, P0 to BQD unconformities show the growth of the contouritic drift deposits during tectonic tilting (Fig. 7). Within the Pliocene sequence, the folding appears to be progressive and diachronic from east to west. At the foot of the Francesc Pagès Bank, P1 reflectors are unconformably lying on the P0 reflector (Fig. 7a). At the foot of the Ramon Margalef High, Pliocene reflectors older than P1 show a more even geometry with constant thicknesses, and P0 is conformable (Fig. 7b).
Parallel to the SAR, the South Alboran Trough corresponds to a syncline that narrows from east to west (Fig. 6). Its northern flank is steeper than the southern one (Fig. 6). The local thickness variations reveal the non-cylindrical folding of the syncline (Figs. 6 and 10). The progressive tilt of the QT1 to QT4 units and internal growth strata reveal a more continuous Quaternary to Pleistocene folding of the South Alboran Trough near the Al-Idrissi Fault zone (Figs. 6 and 9).

\subsubsection{The Al-Idrissi Fault zone}

At present day, the AIF is a NNE-SSW fault zone composed of several segments that locally follow the older NESW trend of the Alboran Ridge (Figs. 10 and 11). The AIF forms a clear positive flower structure across the eastern end of the Francesc Pagès Bank and the western end of the NAR (Fig. 13). The AIF here corresponds to a left-lateral restraining bend, connecting the northern and southern segments. 
This structure partially reactivates NE-SW Pliocene thrusts of the Alboran Ridge and affects the most recent Quaternary sediments (Figs. 11 and 13). The location of the left-lateral restraining bend is highlighted in the present day by the cluster of compressive focal mechanisms (Fig. 4) (Stich et al., 2010). Locally, some Pliocene thrusts appear to be abandoned during the Quaternary (Fig. 13b). The Messinian unconformity is deeper at the western tip of the Alboran Ridge than at the Francesc Pages Bank (Fig. 10), indicating differential uplift/subsidence across the AIF.

At the southern tip of the AIF, NNE-SSW active fault segments correspond to the splay faults distributing the deformation that affect present-day deposits (Figs. 9 and 11). At the seafloor, the fault traces are clear toward the southwest where they offset the Small Al-Idrissi Volcano and link to the Bokoya Fault (Figs. 10 and 11). Below the volcanic facies, poor acoustic penetration prohibits the interpretation of tectonic structures (Fig. 9).

On the north-dipping flank of the South Alboran Ridge, we observe $\mathrm{N} 145^{\circ}$ trending lineaments at the seafloor that correspond to normal faults (Figs. 11 and 14). The fault network forms a $10-12 \mathrm{~km}$ wide shear zone (Fig. 14). The recognition of pockmarks at the seafloor and signal attenuation near the faults on the seismic reflection data suggest fluid seepages along active faults (Fig. 14) (e.g., Judd and Hovland, 2009). Northward, the faults disappear below the seafloor under the present-day contourite drift. These faults affect Q1 and Q2 surfaces demonstrating Late Pleistocene activity (Fig. 14b). Southward, the fault traces disappear against the hinge axis of the Francesc Pagès Bank. Similar NW-SE striking faults affect the seafloor at the southwestern flank of the Francesc Pagès Bank (Fig. 11a). These N145 lineaments correspond to the normal faults highlighted in red on the TOPAS profile (Fig. 11b) that uplift the western block. Despite reduced expression at the seafloor, this fault zone continues southeast, where it affects the whole Plio-Quaternary sequence (Fig. 9). Along the AIF, the vertical offset of the P1 surface is around $100 \mathrm{~m}$ (Fig. 9). Between the N145 faults and the AIF, several fault segments affect the subsurface, highlighting the distributed deformation between the $\mathrm{N} 145^{\circ}$ faults and the AIF with a higher apparent vertical offset along the AIF (Fig. 9).

\section{Discussion}

Our results show at least two phases of tectonic activity from the Early Pliocene to the present day. Based on a literature synthesis (Fig. 15) and our new data, we show that the AlIdrissi Fault zone is a young feature $(<1.8 \mathrm{Ma})$ that profoundly affects regional deformation. The first phase of transpressive deformation started probably during the Tortonian and ends during the Early Quaternary, with the local occurrence of volcanism. The second phase clearly started after 1.8 Ma and continues today. It corresponds to a transtensive tectonic regime. Both phases evidence the overall oblique convergence and control by deep structures, which we detail thereafter.

\subsection{Miocene-Pliocene to Early Quaternary strain partitioning}

Truncated folds (Fig. 6f) indicate that shortening started in the South Alboran Ridge before the Messinian Salinity Crisis (MSC) (Do Couto et al., 2016). The lateral and vertical stratal pattern of the Plio-Quaternary units shows that the shortening occurs mostly during the Pliocene. The overall geometry of deformation in the SAR shows the development of a $\mathrm{N} 65^{\circ}$ shear zone that partitioned the deformation in imbricated folds and thrusts and left-lateral shear (Fig. 6). The change in stacking pattern of the Pliocene deposits along the folds suggests a diachronous growth during the Pliocene with lateral variation in the uplift rates (Figs. 6 and 7). The intraPliocene unconformities, the tilting of the Pliocene units and the aggradation of Quaternary contourite deposits indicate a relative quiescence of the folding during the Quaternary after 2.6 Ma (Juan et al., 2016).

The Pliocene deformation is locally contemporaneous with volcanism. The lateral continuity of the highly reflective facies from west to east suggests that the Small and Big AlIdrissi volcanoes are part of a volcanic structure that is offset by local extensional faults during the Pleistocene (Figs. 8 and 10). This highly reflective material triggers the acoustic masking of the reflections below (Fig. 9), as observed in debris-avalanche deposits elsewhere (Le Friant et al., 2002, 2009). The intercalation of this volcanic material toward the top of the Pl1 unit dates the Small Al-Idrissi Volcano between 4.5 and $5.33 \mathrm{Ma}$ (Fig. 9). The NE-SW distribution of the volcanic material suggests a syn-folding infill of the syncline of the South Alboran Trough (Fig. 10). The local volcanism is contemporaneous with the volcanic activity occurring to the north of the Alboran Ridge, dated between 6 and 4.5 Ma (Duggen et al., 2008). This volcanism occurred above a thinned continental lithosphere (Duggen et al., 2008). The local volcanism suggests that the SAR could have accommodated westward thinning of the crust in the West Alboran Basin from Late Miocene to Pliocene. This extension could be linked to the transition from slab rollback to delamination as proposed in Petit al. (2015).

NE-SW thrust faults distribute the deformation between the Nekor and Jebha Fault and the Alboran Ridge and accommodate the strike-slip motion during the Pliocene. The $20^{\circ}$ angle between the $\mathrm{N} 065^{\circ}$ trend of the SAR and the N085 trend of internal folds evidence a N-S maximum horizontal shortening direction in the SAR (in the present-day structural framework) and indicates left-lateral transpression during the Pliocene folding (e.g., Fossen et al., 1994; Fossen and Tikoff, 1998). It reflects the oblique shortening direction relative to the NE-SW basement faults during the Pliocene. In the SAR, the Pliocene folds show a left-lateral deflection of their hinge lines from the E-W to NE-SW, drawing an 


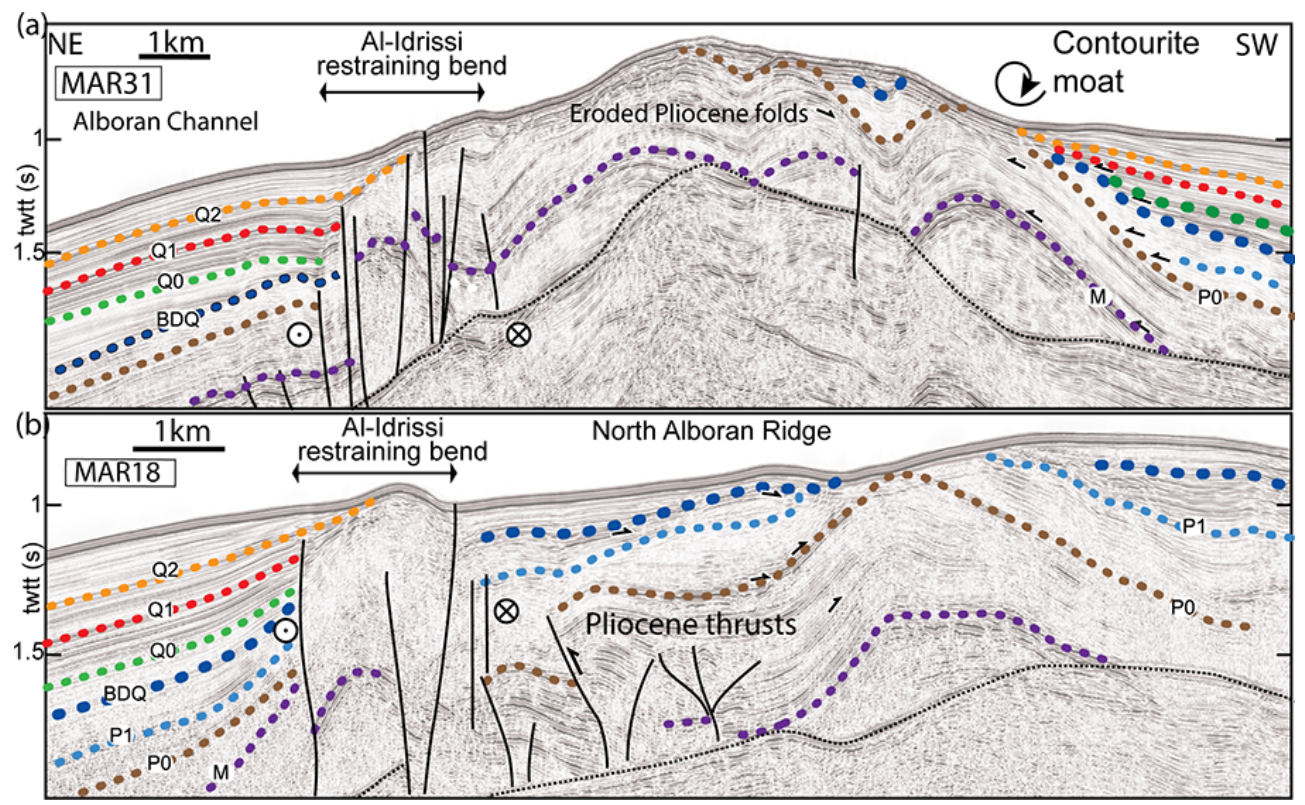

Figure 13. Multichannel seismic lines across the left-lateral restraining bend of the Al-Idrissi Fault zone showing lateral evolution of the tectonic structures in North Alboran Ridge and in the left-lateral restraining bend. (a) The Al-Idrissi Fault zone is a positive flower structure following the front of the Alboran Ridge. (b) The Al-Idrissi Fault zone is a positive flower structure distinct from the Pliocene thrusts and folds.

overall sigmoidal shape (Figs. 6 and 10). Comparison of the structures in the SAR with analogue models of fold-andthrust belt (e.g., ter Borgh et al., 2011; Koyi et al., 2016; Storti et al., 2007) suggests reactivation of basement faults and vertical-axis rotation of the faults (Fig. 16a-c). The development of $\mathrm{E}-\mathrm{W}$ faults and thickness variation in the sedimentary cover, resulting in non-cylindrical thrust wedges, lateral escape of frontal thrust sheets and vertical-axis block rotations demonstrate the influence of a viscous layer. In the SAR, such a weak layer corresponds to the Early Miocene, under-compacted shales at the base of the sedimentary cover (Soto et al., 2008, 2012). Such a weak layer can explain why the deformation is distributed in the SAR, whereas it appears to be more localized in the NAR.

As the direction of relative plate motion between AfricaEurasia has been approximatively constant since $6 \mathrm{Ma}$ (DeMets et al., 2015), left-lateral transpression in the SAR in the present-day framework is unlikely. Instead, it suggests a progressive rotation of basement faults relative to the regional shortening direction since the Pliocene and a progressive change from left-lateral transpressive to more purely compressive deformation (Fig. 16a and b). This model is in accordance with the bookshelf model, which assumes 2$3^{\circ} \mathrm{Ma}^{-1}$ progressive vertical-axis rotation of basement faults since the Pliocene (Meghraoui and Pondrelli, 2013).

The offshore Pliocene oblique compression is equivalent to transpressive tectonics in the Rif onshore (Fig. 15), where the area between the Nekor and Jebha Fault accommodates distributed deformation (Fig. 16a). The passive in- filling of paleo-rias indicates relatively low vertical motion (Romagny et al., 2014) (Fig. 15). After 3.8 Ma, a transition from compression to radial extension (Benmakhlouf et al., 2012) causes NE-SW normal faulting and tectonic tilting of the Moroccan margin (Fig. 16b) (Romagny et al., 2014). Toward the southeast, the Nekor Fault has acted as a transpressive fault zone accommodating the shortening (Ait Brahim et al., 2002; Aït Brahim and Chotin, 1990). The offshore extensional faults prolonging the Nekor Fault were sealed by Pliocene deposits and inverted as blind thrust faults during the Plio-Quaternary (Watts et al., 1993). In the external Rif, in the southwestward continuity of the Nekor Fault, field studies demonstrate NE-SW compression (Roldán et al., 2014). Interpretation of 2D seismic reflection lines indicates thick-skin tectonic from Tortonianearly Messinian to Pliocene times, causing the uplift of intra-mountainous basins around the Nekor Fault (Fig. 16a) (Capella et al., 2016).

\subsection{Quaternary to present-day strain partitioning}

\subsubsection{Evidence of Quaternary tectonic subsidence}

In contrast to the South Alboran Ridge, the recorded uplift increases through time in the North Alboran Ridge until it reaches a maximum around $2.45 \mathrm{Ma}$, related to the development of a popup structure (Martínez-García et al., 2017) (Fig. 15). This contrast could be linked to the incipient activity of the AIF and suggests that the AIF progressively decouples the deformation between the NAR and the SAR from 2.6 


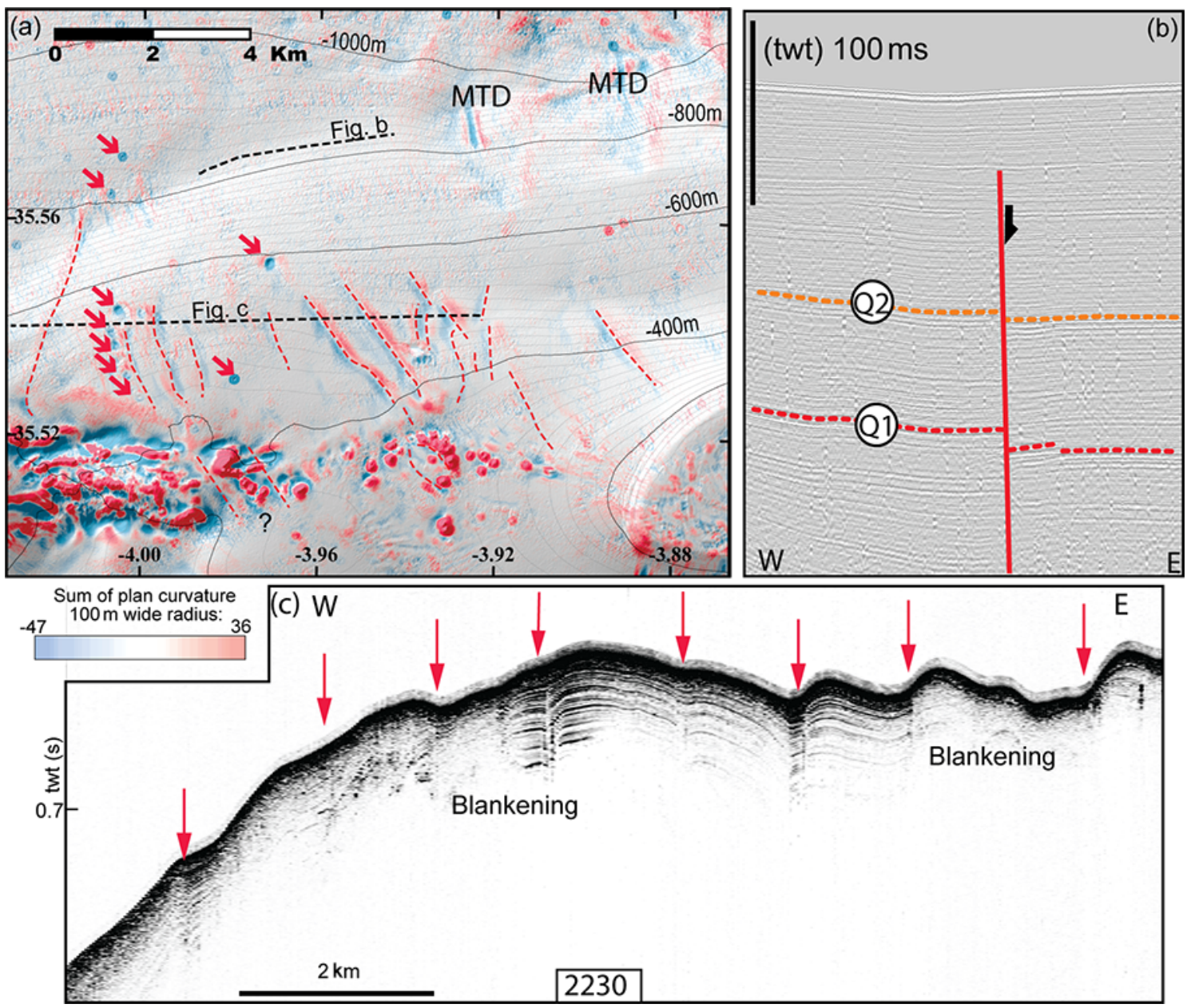

Figure 14. Active structures affecting the northern flank of Francesc Pagès and Ramon Margalef highs. (a) Plan curvature map overlying the shaded bathymetry; red arrows: pockmarks on the seafloor; dashed black lines: seismic lines in the figures (b, c); and dashed red lines: positions of the fault tracks. (b) SPARKER seismic reflection line showing the northward continuity of $145^{\circ} \mathrm{N}$ fault (red line). (c) TOPAS seismic line showing the subsurface of the seafloor. Red arrows: positions of the faults drawn in (a).

to $2.45 \mathrm{Ma}$ (Fig. 16). Before 1.8 Ma, basinward motion of the shelf along the Big Al-Idrissi Volcano and the normal regressive geometry of the shelf wedges support the argument for progradation driven by sediment supply. It may indicate positive accommodation at the coastline (Catuneanu et al., 2011).

After 1.8 Ma, the later Pleistocene transgression is linked to the normal faulting along N-S faults (Figs. 8 and 12). Including the onshore Trougout and Boudinar faults, we interpret the N-S fault network as an en échelon right-stepping set of normal faults (Figs. 10 and 16). Focal mechanism and microstructural studies demonstrate that this fault network is likely to be active with a normal and a sinistral component (Fig. 4) (Poujol et al., 2014). The local stratigraphy recorded the start of the activity of this tectonic structure during the Pleistocene. The depth of the Pleistocene offlap breaks and the geometry of the shelves indicate evident tectonic subsidence contemporaneous with the northward tilting of the margin (Ammar et al., 2007). The Moroccan shelf underwent a local transgression and flooding characterized by the building of transgressive wedges on top of prograding clinoforms (Figs. 8 and 10). The retrogradation of the shoreline started between 1.8 and 1.12 Ma on the margins of the Nekor Basin and the Big Al-Idrissi Volcano (Fig. 16). The depth of the offlap breaks is significantly lower than the maximum depths reached by the sea-level falls at Gibraltar during the Quaternary (Figs. 8 and 12) (Rohling et al., 2014) and proves the tectonic subsidence.

\subsubsection{Evolution and localization of the Al-Idrissi Fault zone}

The beginning of the transgression of the shelf around the Big Al-Idrissi Volcano and the Nekor Basin is approximately synchronous with the last shortening event along the North Alboran Ridge (1.8 to $1.12 \mathrm{Ma}$ ) (Fig. 15). The AIF has progressively propagated southward, activating the $\mathrm{N}-\mathrm{S}$ 


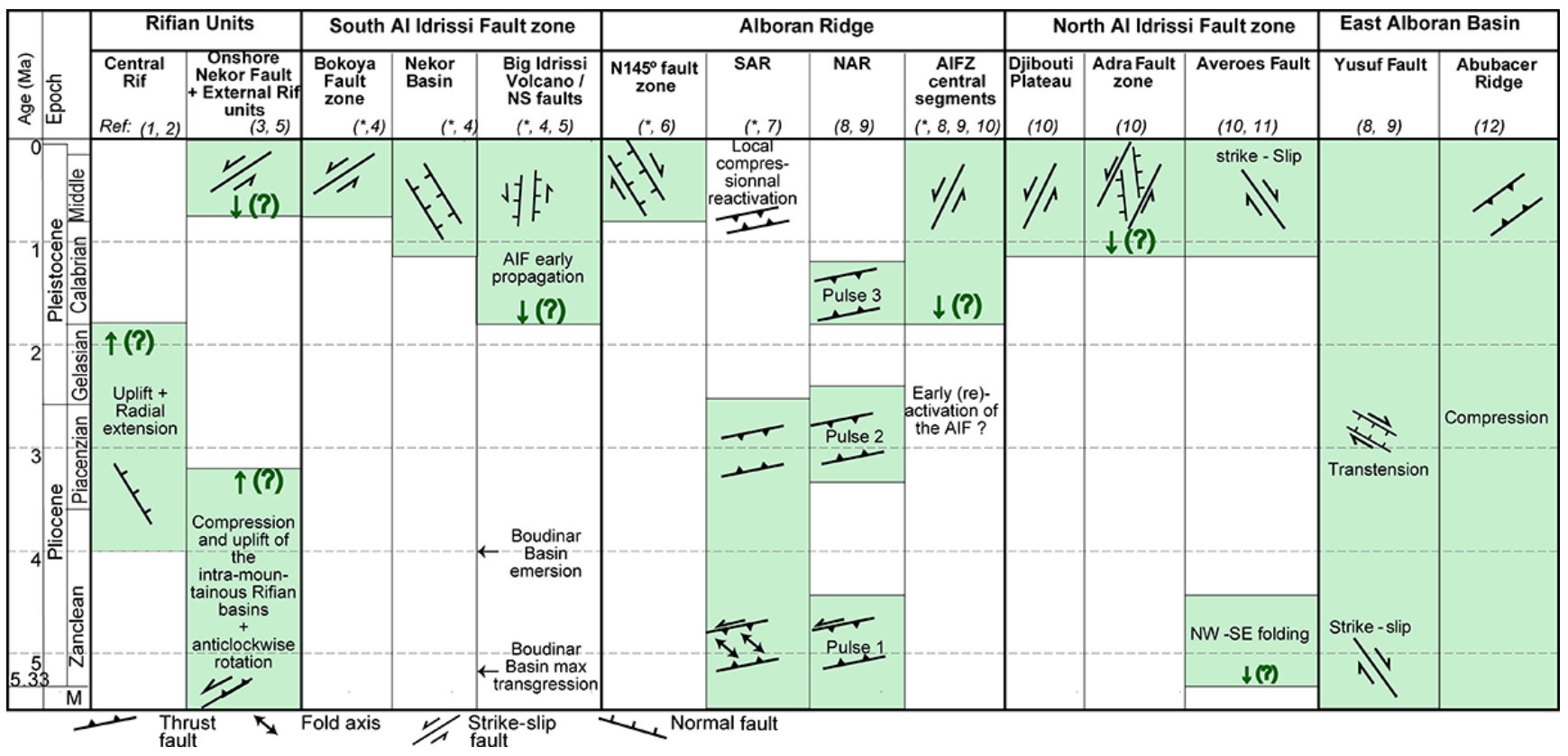

Figure 15. Synthesis of the tectonic events in the Alboran Basin and the Rif from the literature and the present study. * this study; (1) Benmakhlouf et al. (2012); (2) Romagny et al. (2014); (3) Ait Brahim and Chotin (1990), (4) Lafosse et al. (2017); (5) Azdimousa et al. (2006); (6) Galindo-Zaldivar et al. (2018); (7) Juan et al. (2016); (8) Martínez-García et al. (2013); (9) Martínez-García et al. (2017); (10) Gràcia et al. (2019); (11) Perea et al. (2018); and (12) Giaconia et al. (2015). The main tectonic events are in green. Green arrows and question marks indicate the age uncertainties of the main tectonic events.

right-stepping normal fault towards the Boudinar and Nekor Basins (Fig. 16b). The transgression of the shelf of the Big Al-Idrissi Volcano and the subsidence of the Nekor Basin indicate the localization of deformation on a releasing bend activating these $\mathrm{N}-\mathrm{S}$ faults.

The apparent small lateral offset and the localization of deformation on the left-lateral Boussekkour-Bokoya Fault zone after $0.8 \mathrm{Ma}$ suggest that the localization of the deformation along the AIF is a recent feature (Figs. 15 and 16c) (Lafosse et al., 2017). In this context, the normal faults in the Nekor Basin are equivalent to antithetic faults within a horsetail splay that connect to the Trougout Fault and the Nekor faults (Fig. 16b). Such structures are probably related to a relay ramp, like the one proposed in other strike-slip contexts such as the Paleogene Bowey Basin (Peacock and Sanderson, 1995). It denotes a progressive localization of the deformation along the AIF and westward migration of the deformation as proposed in Lafosse et al. (2017) and GalindoZaldivar et al. (2018) (Fig. 16c).

The left-lateral restraining bend in the northern part of the AIF affects the seafloor and was active during the recent seismic crisis (Buforn et al., 2017; Galindo-Zaldívar et al., 2015). In the eastern part of the SAR, the $\mathrm{N} 145^{\circ}$ normal faults are active with an orientation similar to the $\mathrm{N} 140^{\circ}$ normal faults in the Nekor Basin (Figs. 10, 11 and 14) (Lafosse et al., 2017). The local direction of the maximum horizontal stress field and focal mechanisms (Figs. 2b and 4) (Neres et al., 2016) indicate that the fault zone is transtensive with a right-lateral motion. This fault zone may act as the conjugate to the present-day left-lateral AIF or be an extensional structure related to the southern fault tip in the horsetail splay (Fig. 16c).

The inception of the southern Al-Idrissi Fault zone after $1.8 \mathrm{Ma}$ is coherent with similar ages found for the inception of strike-slip tectonics to the north of the NAR where the set of conjugated Al-Idrissi and Averroes strike-slip faults is dated around 1-1.1 Ma (Figs. 1, 15 and 16) (Estrada et al., 2018; Gràcia et al., 2019; Perea et al., 2018). The AIF decouples the deformation in the SAR and the NAR and acts as a transfer fault that connects the shortening north of the Alboran Ridge (Estrada et al., 2018) and the Rifian extrusion along the Nekor Fault. The localization of the deformation along the AIF could be controlled by a Miocene pre-existing structure, as proposed in Martínez-García et al. (2017). At a crustal-scale, geophysical studies show a $\sim 20-30 \mathrm{~km}$ crustal thickness variation in the Al Hoceima region (Diaz et al., 2016). The crustal thickness contrasts are a consequence of Miocene oblique collision (Booth-Rea et al., 2012), lower crustal doming during the Miocene transtension (Le Pourhiet et al., 2014) or removal of lower crust associated with delamination processes (Bezada et al., 2014; Petit et al., 2015). The localization of the deformation on crustal heterogeneities has been evidenced in numerical models, for example, in the cratonic lithosphere (Burov et al., 1998). 


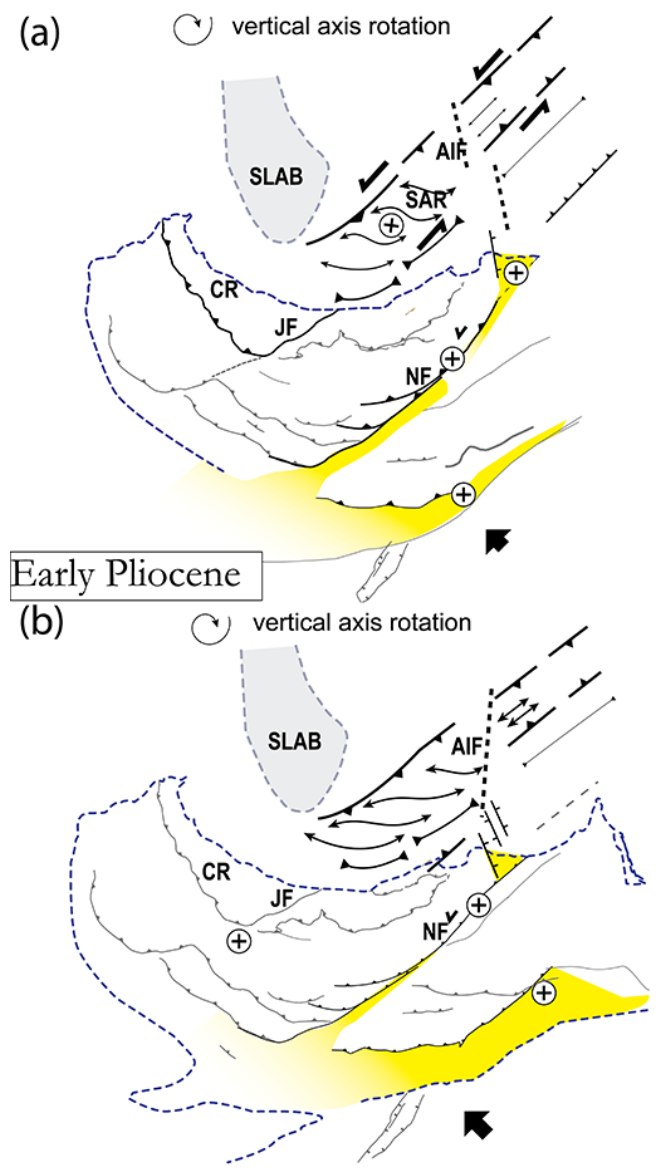

\section{Early Pleistocene}

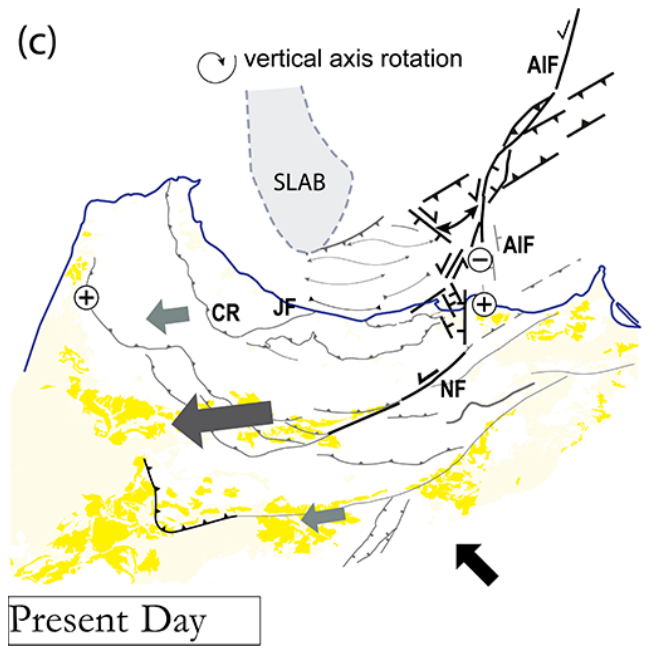

Figure 16. Palinspastic maps of the SAR and the Rif from $5 \mathrm{Ma}$ to the present day are using $14^{\circ}$ clockwise rotation of the Alboran tectonic domain from (a) to (c). Dashed blue line: approximate coastline; continuous blue line: present-day coastline; dark yellow: Miocene-Pliocene onshore basins; light yellow: Pliocene and Quaternary onshore basins; and grey patch: position of the slab remaining approximatively constant below the Alboran Basin during the Plio-Quaternary. Thick grey arrows in (c) indicate the direction and relative amount of extrusion in the central Rif considering a fixed Eurasia. The shortening is accommodated through compressive structures in (a). The initiation of subsidence along the Big Al-Idrissi Volcano and the Moroccan shelf corresponds to (b), and the present-day partitioning of the deformation corresponds to (c). CR: central Rif; JF: Jebha Fault; NF: Nekor Fault; and AIF: Al-Idrissi Fault zone. 
Similarly, the localization of the AIF evidences the control of the crustal thickness variations.

\subsection{Evolution of the southeastern limit of the Alboran tectonic domain}

The Late Miocene-Early Pliocene period in the Rif Belt matches the uplift of the Miocene intra-mountainous basin along the Nekor Fault under compression and left-lateral displacement (Fig. 16a) (Capella et al., 2016). The uplift of those basins corresponds to the change from thin-skin to thick-skin deformation in the external Rif during the inversion of the deep Mesozoic extensional structures (Capella et al., 2016; Martínez-García et al., 2017). Our preferred tectonic scenario consists of a progressive mechanical coupling between the African margin and the Alboran Domain, locking the Nekor Fault in its eastern segment (Fig. 16). This scenario is supported by paleomagnetic data from the External Rif that indicate at least $15^{\circ}$ of counterclockwise rotation since the Upper Miocene (Crespo-Blanc et al., 2016, and references therein). Progressive vertical-axis rotation associated with the shortening of the Alboran Basin decreases the left-lateral shear and increases the compressive deformation along the Alboran Ridge (Fig. 16b). Eventually, the deformation localized on the AIF during the Early Quaternary and has been decoupling the deformation between the NAR and the SAR with a developing transtensive regime since $1.81 \mathrm{Ma}$ (Fig. 16c). This evolution induced a change in strain partitioning along the TASZ illustrated by the transition from a Pliocene left-lateral shearing and folding of the SAR to a transtensive Quaternary deformation localized on the AIF and the Nekor Basin (Fig. 16). Since $6 \mathrm{Ma}$, the relative direction of Africa-Eurasia convergence has remained constant (DeMets et al., 2015), with a NNE-SSW direction in an absolute reference frame (Spakman et al., 2018). This prohibits changes in the direction of far-field forces as the cause for changes in tectonic style in the Alboran Basin as suggested by Martínez-García et al. (2013).

Other scenarios consider that delamination has occurred in the Rif since $6 \mathrm{Ma}$, explaining the structural pattern and extension in the Nekor basin (Bezada et al., 2013; Petit et al., 2015). Extension in the Nekor Basin and strike-slip tectonics along the Al-Idrissi Fault since 1.8-1.12 Ma would then correspond to a reappraisal of mantle delamination. However, this process corresponds to a long-term convective removal of the African lithosphere (Petit et al., 2015). To explain the progressive tectonic reorganization during the Plio-Quaternary, we do not favor this last hypothesis because we do not observe an increase in widespread longwavelength $(>100 \mathrm{~km})$ subsidence that is usually associated with convective thinning of the lithosphere in thermomechanical models (e.g., Le Pourhiet et al., 2006; Valera et al., 2011).

Recent papers (Heit et al., 2017; Mancilla et al., 2015; Sun and Bezada, 2020) suggest that a slab tear propagates from the Betic to the western tip of the Alboran Ridge, with a lithospheric necking distributed from north to south below the West Alboran Basin (Sun and Bezada, 2020). It is unclear how fast this slab tear propagates from the Betic to the study area and how it controls the Plio-Quaternary deformation. Slow uplift and extension since $4 \mathrm{Ma}$ are recorded in the central Rif (Fig. 15) (Romagny et al., 2014) and might mark the inception of the lithospheric necking. Since 1.81.12 Ma, vertical motion has been local, however, and associated with the activity of the AIF. The timing is of primordial importance as demonstrated by thermomechanical models. These models show that slab detachment is a fast process that can occur in less than $1 \mathrm{Ma}$, causing a high-amplitude topographic response (Duretz et al., 2011, 2012). It indicates that the vertical pull due to the sinking lithosphere must be constant during the Plio-Quaternary. It suggests that the necking of the sinking lithosphere is a slow process or is very recent with yet indiscernible effects on the shallower structures in the upper plate.

In this framework, normal strike-slip faulting observed to the north of the NAR (Fig. 1) (Estrada et al., 2018; Giaconia et al., 2015; Gràcia et al., 2012; Grevemeyer et al., 2015) provides additional evidence of indentation by the Africa plate into the Alboran tectonic domain (Estrada et al., 2018; Palano et al., 2015). This indentation is accommodated through the left-lateral AIF and the right-lateral Averroes Yusuf Fault zone (Figs. 1 and 16) in a way similar to that the Palomares Fault zone, transferring the orthogonal shortening of the Iberian margin toward the Carboneras Fault zone and the central Alboran Sea (Estrada et al., 2018; Giaconia et al., 2015). In the SAR and the Nekor Basin, the present-day deformation under the transtensional regime (NNW-SSE to $\mathrm{N}-\mathrm{S}$ extensional network and NNE-SSW strike-slip faults; Figs. 4 and 16) is limited to the east by the Al-Idrissi Fault. The deformation in the NAR is on the contrary clearly compressive (Estrada et al., 2018; Martínez-García et al., 2017), and the geodetic data indicate similar displacements in the $\mathrm{EAB}$ and in the Rifian units east of the Boudinar Basin (Koulali et al., 2011; Vernant et al., 2010). Such a difference in behavior suggests that the AIF may represent the presentday plate boundary between Africa and Alboran Domain.

\section{Conclusion}

This study focused on the tectonic evolution of the southern margin of the Alboran Sea during the Plio-Quaternary, particularly the distinct structural evolutions and interactions of the AIF and the Alboran Ridge and the mechanisms associated with their formation. The analysis of the seismic stratigraphy and the comparison between onshore and offshore tectonic structures led to the following tectonic framework:

1. The Trans-Alboran shear zone, in particular the Alboran Ridge, localized the deformation between the Miocene and the Early Quaternary. Its orientation favors a strike- 
slip movement during its oblique shortening. The folded structures of the South Alboran Ridge underwent significant left-lateral displacement during the Pliocene.

2. Under the indentation of African lithosphere, verticalaxis block rotations led to a progressive compression on the Alboran Ridge and a Pleistocene activation of the Al-Idrissi Fault. The subsidence of both the Nekor Basin and the Big Al-Idrissi Volcano marks the start of the transtensive deformation between 1.8 and $1.12 \mathrm{Ma}$.

3. The area between the South Alboran Ridge and the Nekor Fault is being progressively extruded southwestward, whereas east of the Al-Idrissi Fault, the African lithosphere indents the Alboran tectonic domain. The Al-Idrissi Fault transfers this indentation to the Nekor Basin and has represented an incipient plate boundary since $1.8 \mathrm{Ma}$.

Our findings demonstrate that at the scale of the basin, strike-slip shear zones evolve not only in response to far-field forces but also in response to the local evolution of the AlIdrissi Fault zone. This evolution is fast, being achieved in less than $2 \mathrm{Ma}$, and might be related to lithospheric necking below the West Alboran Basin or mantle delamination below the Rif. In our opinion, the indentation of the African lithosphere into the Alboran tectonic domain explains better the scale and timing of the deformation in the Al-Idrissi Fault. Additional modeling could help to better understand the different processes. Further research is needed to better understand what drives the evolution of such large scale-strike slip structures.

Data availability. Seismic profiles presented in this article are provided in the Supplement. The bathymetry of the seafloor provided in this article is not publicly available.

Supplement. The supplement related to this article is available online at: https://doi.org/10.5194/se-11-741-2020-supplement.

Author contributions. ML wrote the paper and conducted the study. Ed'A and CG led the oceanic surveys Marlboro-1, 2 and SARAS. They contributed to the study and to the redaction of the present paper. AR contributed to the data acquisition and processing and the redaction of the present paper. JS contributed to the redaction of the present paper. FE contributed to the data acquisition and processing. MJC contributed to the stratigraphic interpretation. JTV contributed to the data acquisition and processing. JGZ and GE contributed to the data acquisition and processing. They are the PIs of the INCRISIS survey. GE also contributed to the stratigraphic correlations and interpretations. BA contributed to the stratigraphic correlations and interpretations. AA contributed to the data acquisition.
Competing interests. The authors declare that they have no conflict of interest.

Acknowledgements. We thank the members of the SARAS and Marlboro cruises in 2011 and 2012. We thank Emanuele Lodolo, Jacques Déverchère, Guillermo Booth-Rea for their helpful comments and discussion. We also thank the editor, Federico Rossetti, for the attention provided to this article. This work was funded by the French program Actions Marges, the EUROFLEETS program (FP7/2007-2013; no. 228344) and project FICTS-2011-03-01. The French program ANR-17-CE03-0004 also supported this work. Seismic reflection data were processed using the Seismic UNIX SU and Geovecteur software. The processed seismic data were interpreted using Kingdom IHS Suite $\bigcirc$ software. This work also benefited from the Fauces Project (Ref CTM2015-65461-C2-R; MINCIU/FEDER) financed by Ministerio de Economía y Competitividad y al Fondo Europeo de Desarrollo Regiona (FEDER).

Financial support. This research has been supported by the CNRSINSU-TOTAL-BRGM-IFREMER Actions Marges program, EUROFLEETS program FP7/2007-2013 (grant no. 228344), EU Regional Structural Fund (grant no. FICTS-2011-03-01) and DAMAGE Project (project no. FEDER/CGL2016-80687-R AEI), Fauces Project (project no. FEDER/CTM2015-65461-C2-R; MINCI), ALBAMAR Project (project no. ANR/ANR-17-CE03-0004).

Review statement. This paper was edited by Federico Rossetti and reviewed by Emanuele Lodolo, Jacques Déverchère, and Guillermo Booth-Rea.

\section{References}

Ait Brahim, L. and Chotin, P.: Oriental Moroccan Neogene volcanism and strike-slip faulting, J. Afr. Earth Sci., 11, 273-280, https://doi.org/10.1016/0899-5362(90)90005-Y, 1990.

Ait Brahim, L., Chotin, P., Hinaj, S., Abdelouafi, A., El Adraoui, A., Nakcha, C., Dhont, D., Charroud, M., Sossey Alaoui, F., Amrhar, M., Bouaza, A., Tabyaoui, H., and Chaouni, A.: Paleostress evolution in the Moroccan African margin from Triassic to Present, Tectonophysics, 357, 187-205, https://doi.org/10.1016/S00401951(02)00368-2, 2002.

Alvarez-Marrón, J.: 26. Pliocene to Holocene structure of the eastern Alboran Sea (Western Mediterranean), Proc Ocean Drill Program Sci Results, 161, 345-355, 1999.

Ammar, A., Mauffret, A., Gorini, C., and Jabour, H.: The tectonic structure of the Alboran Margin of Morocco, Revista de la Sociedad Geológica de España, 20, 247-271, 2007.

Azdimousa, A., Poupeau, G., Rezqui, H., Asebriy, L., Bourgois, J. and Aït Brahim, L.: Géodynamique des bordures méridionales de la mer d'Alboran; application de la stratigraphie séquentielle dans le bassin néogène de Boudinar (Rif oriental, Maroc), Bulletin de l'Institut Scientifique, Rabat, 28, 9-18, 2006.

Ballesteros, M., Rivera, J., Muñoz, A., Muñoz-Martín, A., Acosta, J., Carbó, A., and Uchupi, E.: Alboran Basin, southern Spain-Part II: Neogene tectonic implications for 
the orogenic float model, Mar. Petrol. Geol., 25, 75-101, https://doi.org/10.1016/j.marpetgeo.2007.05.004, 2008.

Benmakhlouf, M., Galindo-Zaldívar, J., Chalouan, A., Sanz de Galdeano, C., Ahmamou, M., and López-Garrido, A. C.: Inversion of transfer faults: The Jebha-Chrafate fault (Rif, Morocco), J. Afr. Earth Sci., 73-74, 33-43, https://doi.org/10.1016/j.jafrearsci.2012.07.003, 2012.

Bezada, M. J., Humphreys, E. D., Toomey, D. R., Harnafi, M., Dávila, J. M., and Gallart, J.: Evidence for slab rollback in westernmost Mediterranean from improved upper mantle imaging, Earth Planet. Sc. Lett., 368, 51-60, https://doi.org/10.1016/j.epsl.2013.02.024, 2013.

Bezada, M. J., Humphreys, E. D., Davila, J. M., Carbonell, R., Harnafi, M., Palomeras, I., and Levander, A.: Piecewise delamination of Moroccan lithosphere from beneath the Atlas Mountains, Geochem. Geophy. Geosy., 15, 975-985, https://doi.org/10.1002/2013GC005059, 2014.

Bezzeghoud, M. and Buforn, E.: Source parameters of the 1992 Melilla (Spain, MW=4.8), 1994 Alhoceima (Morocco, MW = 5.8), and 1994 Mascara (Algeria, MW = 5.7) earthquakes and seismotectonic implications, B. Seismol. Soc. Am., 89, 359372, 1999.

Biggs, J., Bergman, E., Emmerson, B., Funning, G. J., Jackson, J., Parsons, B., and Wright, T. J.: Fault identification for buried strike-slip earthquakes using InSAR: The 1994 and 2004 Al Hoceima, Morocco earthquakes, Geophys. J. Int., 166, 1347-1362, https://doi.org/10.1111/j.1365-246X.2006.03071.x, 2006.

Bird, P.: An updated digital model of plate boundaries, Geochem. Geophy. Geosy., 4, 1027, https://doi.org/10.1029/2001gc000252, 2003.

Booth-Rea, G., Ranero, C., Martinez-Martinez, J. M., and Grevemeyer, I.: Crustal types and Tertiary tectonic evolution of the Alboran sea, western Mediterranean, Geochem. Geophy. Geosy., 8, Q10005, https://doi.org/10.1029/2007GC001639, 2007.

Booth-Rea, G., Jabaloy-Sánchez, A., Azdimousa, A., Asebriy, L., Vílchez, M. V., and Martínez-Martínez, J. M.: Upper-crustal extension during oblique collision: the Temsamane extensional detachment (eastern Rif, Morocco): The Temsamane extensional detachment (eastern Rif, Morocco), Terra Nova, 24, 505-512, https://doi.org/10.1111/j.1365-3121.2012.01089.x, 2012.

Bourgois, J., Mauffret, A., Ammar, A., and Demnati, A.: Multichannel seismic data imaging of inversion tectonics of the Alboran Ridge (Western Mediterranean Sea), Geo-Mar. Lett., 12, 117122, 1992.

Buforn, E., Pro, C., Sanz de Galdeano, C., Cantavella, J. V., Cesca, S., Caldeira, B., Udías, A., and Mattesini, M.: The 2016 south Alboran earthquake $\left(\mathrm{M}_{\mathrm{W}}=6.4\right)$ : A reactivation of the Ibero-Maghrebian region?, Tectonophysics, 712-713, 704-715, https://doi.org/10.1016/j.tecto.2017.06.033, 2017.

Burov, E., Jaupart, C., and Mareschal, J. C.: Large-scale crustal heterogeneities and lithospheric strength in cratons, Earth Planet. Sc. Lett., 164, 205-219, https://doi.org/10.1016/S0012821X(98)00205-2, 1998.

Calvert, A., Gomez, F., Seber, D., Barazangi, M., Jabour, N., Ibenbrahim, A., and Demnati, A.: An integrated geophysical investigation of recent seismicity in the Al-Hoceima region of North Morocco, B. Seismol. Soc. Am., 87, 637-651, 1997.

Calvert, A., Sandvol, E., Seber, D., Barazangi, M., Roecker, S., Mourabit, T., Vidal, F., Alguacil, G., and Jabour, N.: Geody- namic evolution of the lithosphere and upper mantle beneath the Alboran region of the western Mediterranean: Constraints from travel time tomography, J. Geophys. Res., 105, 10871-10898, https://doi.org/10.1029/2000JB900024, 2000.

Capella, W., Matenco, L., Dmitrieva, E., Roest, W. M. J., Hessels, S., Hssain, M., Chakor-Alami, A., Sierro, F. J., and Krijgsman, W.: Thick-skinned tectonics closing the Rifian Corridor, Tectonophysics, https://doi.org/10.1016/j.tecto.2016.09.028, 2016.

Catuneanu, O.: Principles of sequence stratigraphy, 1st edn., reprinted, Elsevier, Amsterdam, 2007.

Catuneanu, O., Galloway, W. E., Kendall, C. G. St. C., Miall, A. D., Posamentier, H. W., Strasser, A., and Tucker, M. E.: Sequence Stratigraphy: Methodology and Nomenclature, Newsl. Stratigr., 44, 173-245, https://doi.org/10.1127/00780421/2011/0011, 2011.

Chalouan, A., Saji, R., Michard, A., and Bally, W. A.: Neogene tectonic evolution of the southwestern Alboran basin as inferred from seismic data off Morocco, AAPG Bull., 81, 1161-1184, 1997.

Chalouan, A., Michard, A., El Kadiri, K., Negro, F., Frizon de Lamotte, D., Soto, J. I., and Saddiqi, O.: The Rif Belt, in: Continental evolution: the geology of Morocco, edited by: Michard, A., Saddiqi, O., Chalouan, A., and Lamotte, D. F., Lect. Notes Earth Sci., 116, 203-302, 2008.

Comas, M. C., Platt, J. P., Soto, J. I., and Watts, A. B.: The origin and Tectonic History of the Alboran Basin: Insights from Leg 161 Results, Proceedings of the Ocean Drilling Program Scientific Results, 161, 555-580, 1999.

Crespo-Blanc, A., Comas, M., and Balanyá, J. C.: Clues for a Tortonian reconstruction of the Gibraltar Arc: Structural pattern, deformation diachronism and block rotations, Tectonophysics, https://doi.org/10.1016/j.tecto.2016.05.045, 2016.

Custódio, S., Lima, V., Vales, D., Cesca, S., and Carrilho, F.: Imaging active faulting in a region of distributed deformation from the joint clustering of focal mechanisms and hypocentres: Application to the Azores-western Mediterranean region, Tectonophysics, 676, 70-89, https://doi.org/10.1016/j.tecto.2016.03.013, 2016.

d'Acremont, E., Gutscher, M.-A., Rabaute, A., Mercier de Lépinay, B., Lafosse, M., Poort, J., Ammar, A., Tahayt, A., Le Roy, P., Smit, J., Do Couto, D., Cancouët, R., Prunier, C., Ercilla, G., and Gorini, C.: High-resolution imagery of active faulting offshore Al Hoceima, Northern Morocco, Tectonophysics, 683, 308-324,https://doi.org/10.1016/j.tecto.2014.06.008, 2014.

DeMets, C., Iaffaldano, G., and Merkouriev, S.: High-resolution Neogene and Quaternary estimates of Nubia-Eurasia-North America Plate motion, Geophys. J. Int., 203, 416-427, https://doi.org/10.1093/gji/ggv277, 2015.

Diaz, J., Gallart, J., and Carbonell, R.: Moho topography beneath the Iberian-Western Mediterranean region mapped from controlled-source and natural seismicity surveys, Tectonophysics, 692, 74-85, https://doi.org/10.1016/j.tecto.2016.08.023, 2016.

Díaz, J., Gil, A., Carbonell, R., Gallart, J., and Harnafi, M.: Constraining the crustal root geometry beneath Northern Morocco, Tectonophysics, 689, 14-24, https://doi.org/10.1016/j.tecto.2015.12.009, 2016. 
Dillon, W. P., Robb, J. M., Greene, H. G., and Lucena, J. C.: Evolution of the continental margin of southern Spain and the Alboran Sea, Mar. Geol., 36, 205-226, https://doi.org/10.1016/00253227(80)90087-0, 1980.

Do Couto, D.: Evolution géodynamique de la mer d'Alboran par l'étude des bassin sédimentaires, Université Pierre et Marie Curie, Paris, France, 16 January 2014.

Do Couto, D., Gumiaux, C., Augier, R., Lebret, N., Folcher, N., Jouannic, G., Jolivet, L., Suc, J.-P., and Gorini, C.: Tectonic inversion of an asymmetric graben: Insights from a combined field and gravity survey in the Sorbas basin, Tectonics, 33, 1360-1385, https://doi.org/10.1002/2013TC003458, 2014.

Do Couto, D., Gorini, C., Jolivet, L., Lebret, N., Augier, R., Gumiaux, C., d'Acremont, E., Ammar, A., Jabour, H., and Auxietre, J.-L.: Tectonic and stratigraphic evolution of the Western Alboran Sea Basin in the last 25 Myrs, Tectonophysics, 677-678, 280-311, https://doi.org/10.1016/j.tecto.2016.03.020, 2016.

Duggen, S., Hoernle, K., van den Bogaard, P., and Harris, C.: Magmatic evolution of the Alboran region: The role of subduction in forming the western Mediterranean and causing the Messinian Salinity Crisis, Earth Planet. Sc. Lett., 218, 91-108, https://doi.org/10.1016/S0012-821X(03)00632-0, 2004.

Duggen, S., Hoernle, K., Klügel, A., Geldmacher, J., Thirlwall, M., Hauff, F., Lowry, D., and Oates, N.: Geochemical zonation of the Miocene Alborán Basin volcanism (westernmost Mediterranean): geodynamic implications, Contrib. Mineral. Petr., 156, 577-593, https://doi.org/10.1007/s00410-008-0302-4, 2008.

Duretz, T., Gerya, T. V., and May, D. A.: Numerical modelling of spontaneous slab breakoff and subsequent topographic response, Tectonophysics, 502, 244-256, https://doi.org/10.1016/j.tecto.2010.05.024, 2011.

Duretz, T., Schmalholz, S. M., and Gerya, T. V.: Dynamics of slab detachment, Geochem. Geophy. Geosy., 13, Q03020, https://doi.org/10.1029/2011GC004024, 2012.

Dziewonski, A. M., Chou, T.-A., and Woodhouse, J. H.: Determination of earthquake source parameters from waveform data for studies of global and regional seismicity, J. Geophys. Res., 86, 2825-2852, https://doi.org/10.1029/JB086iB04p02825, 1981.

Ekström, G., Nettles, M., and Dziewoński, A. M.: The global CMT project 2004-2010: Centroid-moment tensors for 13,017 earthquakes, Physics of the Earth and Planetary Interiors, 200-201, 1-9, https://doi.org/10.1016/j.pepi.2012.04.002, 2012.

El Alami, S. O., Tadili, B. A., Cherkaoui, T. E., Medina, F., Ramdani, M., Brahim, L. A., and Harnafi, M.: The Al Hoceima earthquake of May 26, 1994 and its aftershocks: a seismotectonic study, Ann. Geofis., 41, 519-537, 1998.

El Azzouzi, M., Bellon, H., Coutelle, A., and Réhault, J.-P.: Miocene magmatism and tectonics within the Peri-Alboran orogen (western Mediterranean), J. Geodyn., 77, 171-185, https://doi.org/10.1016/j.jog.2014.02.006, 2014.

Ercilla, G., Juan, C., Hernández-Molina, F. J., Bruno, M., Estrada, F., Alonso, B., Casas, D., Farran, M., Llave, E., García, M., Vázquez, J. T., D’Acremont, E., Gorini, C., Palomino, D., Valencia, J., El Moumni, B., and Ammar, A.: Significance of bottom currents in deep-sea morphodynamics: An example from the Alboran Sea, Mar. Geol., 378, 157-170, https://doi.org/10.1016/j.margeo.2015.09.007, 2016.

Estrada, F., Ercilla, G., Gorini, C., Alonso, B., Vázquez, J. T., García-Castellanos, D., Juan, C., Maldonado, A., Ammar, A., and Elabbassi, M.: Impact of pulsed Atlantic water inflow into the Alboran Basin at the time of the Zanclean flooding, Geo-Mar. Lett., 31, 361-376, https://doi.org/10.1007/s00367-011-0249-8, 2011.

Estrada, F., Vázquez, J. T., Ercilla, G., Alonso, B., d'Acremont, E., Gorini, Ch., Gomez-Ballesteros, M., Fernández-Puga, M. C., Ammar, A., and El Moumni, B.: Inversión tectónica reciente de la zona central de Alborán, in: Una aproximación multidisciplinar al estudio de las fallas activas, los terremotos y el riesgo sísmico, edited by: Álvarez-Gomez, J. A. and MartínGonzález, F., Segunda reunión Ibérica sobre fallas activas y paleosismología, Lorca, Murcia, España, 93-96, ISBN: 978-84-6172049-1, 2014.

Estrada, F., Galindo-Zaldívar, J., Vázquez, Gemma, E., D'Acremont, E., Belén, B., and Gorini, C.: Tectonic indentation in the central Alboran Sea (westernmost Mediterranean), Terra Nova, 30, 24-33, https://doi.org/10.1111/ter.12304, 2018.

Faccenna, C., Becker, T. W., Lucente, F. P., Jolivet, L., and Rossetti, F.: History of subduction and back-arc extension in the Central Mediterranean, Geophys. J. Int., 145, 1-21, 2001.

Fossen, H. and Tikoff, B.: Extended models of transpression and transtension, and application to tectonic settings, Geol. Soc. Spec. Publ., 135, 15-33, https://doi.org/10.1144/GSL.SP.1998.135.01.02, 1998.

Fossen, H., Tikoff, B., and Teyssier, C.: Strain modeling of transpressional and transtensional deformation, Norsk Geol. Tidsskr., 74, 134-145, 1994.

Galindo-Zaldívar, J., González-Lodeiro, F., and Jabaloy, A.: Stress and palaeostress in the Betic-Rif cordilleras (Miocene to the present), Tectonophysics, 227, 105-126, https://doi.org/10.1016/0040-1951(93)90090-7, 1993.

Galindo-Zaldívar, J., Azzouz, O., Chalouan, A., Pedrera, A., Ruano, P., Ruiz-Constán, A., Sanz de Galdeano, C., Marín-Lechado, C., López-Garrido, A., Anahnah, F., and Benmakhlouf, M.: Extensional tectonics, graben development and fault terminations in the eastern Rif (Bokoya-Ras Afraou area), Tectonophysics, 663, 140-149, https://doi.org/10.1016/j.tecto.2015.08.029, 2015.

Galindo-Zaldivar, J., Ercilla, G., Estrada, F., Catalán, M., d'Acremont, E., Azzouz, O., Casas, D., Chourak, M., Vazquez, J. T., Chalouan, A., Galdeano, C. S. de, Benmakhlouf, M., Gorini, C., Alonso, B., Palomino, D., Rengel, J. A., and Gil, A. J.: Imaging the Growth of Recent Faults: The Case of 20162017 Seismic Sequence Sea Bottom Deformation in the Alboran Sea (Western Mediterranean), Tectonics, 37, 2513-2530, https://doi.org/10.1029/2017TC004941, 2018.

Garcia-Castellanos, D. and Villasenor, A.: Messinian salinity crisis regulated by competing tectonics and erosion at the Gibraltar arc, Nature, 480, 359-363, 2011.

Gensous, B., Tesson, M., and Winnock, E.: La marge meridionale de la mer d'alboran: caracteres structurosedimentaires et evolution recente, Mar. Geol., 72, 341-370, https://doi.org/10.1016/0025-3227(86)90127-1, 1986.

Giaconia, F., Booth-Rea, G., Ranero, C. R., Gràcia, E., Bartolome, R., Calahorrano, A., Lo Iacono, C., Vendrell, M. G., Cameselle, A. L., Costa, S., Gómez de la Peña, L., Martínez-Loriente, S., Perea, H., and Viñas, M.: Compressional tectonic inversion of the Algero-Balearic basin: Latemost Miocene to present oblique convergence at the Palomares 
margin (Western Mediterranean), Tectonics, 34, 2015TC003861, https://doi.org/10.1002/2015TC003861, 2015.

Gill, R. C. O., Aparicio, A., El Azzouzi, M., Hernandez, J., Thirlwall, M. F., Bourgois, J., and Marriner, G. F.: Depleted arc volcanism in the Alboran Sea and shoshonitic volcanism in Morocco: geochemical and isotopic constraints on Neogene tectonic processes, Lithos, 78, 363-388, https://doi.org/10.1016/j.lithos.2004.07.002, 2004.

Gómez de la Peña, L., Ranero, C. R., and Gràcia, E.: The Crustal Domains of the Alboran Basin (Western Mediterranean), Tectonics, 37, 3352-3377, https://doi.org/10.1029/2017TC004946, 2018.

Gràcia, E., Pallàs, R., Soto, J. I., Comas, M., Moreno, X., Masana, E., Santanach, P., Diez, S., García, M., and Dañobeitia, J.: Active faulting offshore SE Spain (Alboran Sea): Implications for earthquake hazard assessment in the Southern Iberian Margin, Earth Planet. Sci. Lett., 241, 734-749, https://doi.org/10.1016/j.epsl.2005.11.009, 2006.

Gràcia, E., Bartolome, R., Lo Iacono, C., Moreno, X., Stich, D., Martínez-Diaz, J. J., Bozzano, G., Martínez-Loriente, S., Perea, H., Diez, S., Masana, E., Dañobeitia, J. J., Tello, O., Sanz, J. L., Carreño, E., and EVENT-SHELF Team: Acoustic and seismic imaging of the Adra Fault (NE Alboran Sea): in search of the source of the 1910 Adra earthquake, Nat. Hazards Earth Syst. Sci., 12, 3255-3267, https://doi.org/10.5194/nhess12-3255-2012, 2012.

Gràcia, E., Grevemeyer, I., Bartolomé, R., Perea, H., MartínezLoriente, S., Gómez de la Peña, L., Villaseñor, A., Klinger, Y., Lo Iacono, C., Diez, S., Calahorrano, A., Camafort, M., Costa, S., d'Acremont, E., Rabaute, A., and Ranero, C. R.: Earthquake crisis unveils the growth of an incipient continental fault system, Nat. Commun., 10, 3482, https://doi.org/10.1038/s41467019-11064-5, 2019.

Grevemeyer, I., Gràcia, E., Villaseñor, A., Leuchters, W., and Watts, A. B.: Seismicity and active tectonics in the Alboran Sea, Western Mediterranean: Constraints from an offshore-onshore seismological network and swath bathymetry data, J. Geophys. Res.-Sol. Ea., 120, 8348-8365, https://doi.org/10.1002/2015JB012073, 2015.

Gutscher, M.-A., Malod, J., Rehault, J.-P., Contrucci, I., Klingelhoefer, F., Mendes-Victor, L., and Spakman, W.: Evidence for active subduction beneath Gibraltar, Geology, 30, 1071-1074, https://doi.org/10.1130/00917613(2002)030<1071:EFASBG>2.0.CO;2, 2002.

Hatzfeld, D., Caillot, V., Cherkaoui, T.-E., Jebli, H., and Medina: Microearthquake seismicity and fault plane solutions around the Nékor strike-slip fault, Morocco, Earth Planet. Sc. Lett., 120, 3141, https://doi.org/10.1016/0012-821X(93)90021-Z, 1993.

Heit, B., Mancilla, F. de L., Yuan, X., Morales, J., Stich, D., Martín, R., and Molina-Aguilera, A.: Tearing of the mantle lithosphere along the intermediate-depth seismicity zone beneath the Gibraltar Arc: The onset of lithospheric delamination, Geophys. Res. Lett., 44, 4027-4035, https://doi.org/10.1002/2017GL073358, 2017.

Jolivet, L. and Faccenna, C.: Mediterranean extension and the Africa-Eurasia collision, Tectonics, 19, 1095-1106, https://doi.org/10.1029/2000TC900018, 2000.

Jolivet, L., Augier, R., Faccenna, C., Negro, F., Rimmele, G., Agard, P., Robin, C., Rossetti, F., and Crespo-Blanc, A.: Sub- duction, convergence and the mode of backarc extension in the Mediterranean region, B. Soc. Geol. Fr., 179, 525-550, https://doi.org/10.2113/gssgfbull.179.6.525, 2008.

Jolivet, L., Faccenna, C., and Piromallo, C.: From mantle to crust: Stretching the Mediterranean, Earth Planet. Sc. Lett., 285, 198209, https://doi.org/10.1016/j.eps1.2009.06.017, 2009.

Juan, C., Ercilla, G., Javier Hernández-Molina, F., Estrada, F., Alonso, B., Casas, D., García, M., Farran, M., Llave, E., Palomino, D., Vázquez, J.-T., Medialdea, T., Gorini, C., D’Acremont, E., El Moumni, B., and Ammar, A.: Seismic evidence of current-controlled sedimentation in the Alboran Sea during the Pliocene and Quaternary: Palaeoceanographic implications, Mar. Geol., 378, 292-311, https://doi.org/10.1016/j.margeo.2016.01.006, 2016.

Judd, A. and Hovland, M.: Seabed Fluid Flow: The Impact on Geology, Biology and the Marine Environment, Cambridge University Press, Cambridge, 2009.

Koulali, A., Ouazar, D., Tahayt, A., King, R. W., Vernant, P., Reilinger, R. E., McClusky, S., Mourabit, T., Davila, J. M., and Amraoui, N.: New GPS constraints on active deformation along the Africa-Iberia plate boundary, Earth Planet. Sc. Lett., 308, 211-217, https://doi.org/10.1016/j.eps1.2011.05.048, 2011.

Koyi, H., Nilfouroushan, F., and Hessami, K.: Modelling role of basement block rotation and strike-slip faulting on structural pattern in cover units of fold-and-thrust belts, Geol. Mag., 153, 827844, https://doi.org/10.1017/S0016756816000595, 2016.

Lafosse, M., d'Acremont, E., Rabaute, A., Mercier de Lépinay, B., Tahayt, A., Ammar, A., and Gorini, C.: Evidence of quaternary transtensional tectonics in the Nekor basin (NE Morocco), Basin Res., 29, 470-489, https://doi.org/10.1111/bre.12185, 2017.

Leblanc, D. and Olivier, P.: Role of strike-slip faults in the Betic-Rifian orogeny, Tectonophysics, 101, 345-355, https://doi.org/10.1016/0040-1951(84)90120-3, 1984.

Le Friant, A., Boudon, G., Komorowski, J.-C., and Deplus, C.: L'île de la Dominique, à l'origine des avalanches de débris les plus volumineuses de l'arc des Petites Antilles, C. R. Geosci., 334, 235 243, https://doi.org/10.1016/S1631-0713(02)01742-X, 2002.

Le Friant, A., Boudon, G., Arnulf, A., and Robertson, R. E. A.: Debris avalanche deposits offshore St. Vincent (West Indies): Impact of flank-collapse events on the morphological evolution of the island, J. Volcanol. Geoth. Res., 179, 1-10, https://doi.org/10.1016/j.jvolgeores.2008.09.022, 2009.

Le Pourhiet, L., Gurnis, M., and Saleeby, J.: Mantle instability beneath the Sierra Nevada Mountains in California and Death Valley extension, Earth Planet. Scie Lett., 251, 104-119, https://doi.org/10.1016/j.epsl.2006.08.028, 2006.

Le Pourhiet, L., Huet, B., and Traoré, N.: Links between longterm and short-term rheology of the lithosphere: Insights from strike-slip fault modelling, Tectonophysics, 631, 146-159, https://doi.org/10.1016/j.tecto.2014.06.034, 2014.

Lisiecki, L. E. and Raymo, M. E.: A Pliocene-Pleistocene stack of 57 globally distributed benthic $\delta^{18} \mathrm{O}$ records, Paleoceanography, 20, PA1003, https://doi.org/10.1029/2004PA001071, 2005.

Mancilla, F. de L., Booth-Rea, G., Stich, D., Pérez-Peña, J. V., Morales, J., Azañón, J. M., Martin, R., and Giaconia, F.: Slab rupture and delamination under the Betics and Rif constrained from receiver functions, Tectonophysics, 663, 225-237, https://doi.org/10.1016/j.tecto.2015.06.028, 2015. 
Martínez-Díaz, J. J. and Hernández-Enrile, J. L.: Neotectonics and morphotectonics of the southern Almería region (Betic Cordillera-Spain) kinematic implications, Int. J. Earth Sci., 93, 189-206, https://doi.org/10.1007/s00531-003-0379-y, 2004.

Martínez-García, P., Soto, J. I., and Comas, M.: Recent structures in the Alboran Ridge and Yusuf fault zones based on swath bathymetry and sub-bottom profiling: evidence of active tectonics, Geo-Mar. Lett., 31, 19-36, https://doi.org/10.1007/s00367010-0212-0, 2011.

Martínez-García, P., Comas, M., Soto, J. I., Lonergan, L., and Watts, A. B.: Strike-slip tectonics and basin inversion in the Western Mediterranean: the Post-Messinian evolution of the Alboran Sea, Basin Res., 25, 361-387, https://doi.org/10.1111/bre.12005, 2013.

Martínez-García, P., Comas, M., Lonergan, L., and Watts, A. B.: From extension to shortening: tectonic inversion distributed in time and space in the Alboran Sea, Western Mediterranean: Tectonic inversion in the Alboran Sea, Tectonics, 36, 2777-2805, https://doi.org/10.1002/2017TC004489, 2017.

Medina, F. and Cherkaoui, T.-E.: The South-Western Alboran Earthquake Sequence of January-March 2016 and Its Associated Coulomb Stress Changes, Open Journal of Earthquake Research, 6, 35-54, https://doi.org/10.4236/ojer.2017.61002, 2017.

Meghraoui, M. and Pondrelli, S.: Active faulting and transpression tectonics along the plate boundary in North Africa, Ann. Geophys., 55, 955-967, https://doi.org/10.4401/ag-4970, 2013.

Muñoz, A., Ballesteros, M., Montoya, I., Rivera, J., Acosta, J., and Uchupi, E.: Alborán Basin, southern Spain-Part I: Geomorphology, Mar. Petrol. Geol., 25, 59-73, https://doi.org/10.1016/j.marpetgeo.2007.05.003, 2008.

Neres, M., Carafa, M. M. C., Fernandes, R. M. S., Matias, L., Duarte, J. C., Barba, S., and Terrinha, P.: Lithospheric deformation in the Africa-Iberia plate boundary: Improved neotectonic modeling testing a basal-driven Alboran plate, J. Geophys. Res.-Sol. Ea., 121, 6566-6596, https://doi.org/10.1002/2016JB013012, 2016.

Nocquet, J.-M.: Present-day kinematics of the Mediterranean: A comprehensive overview of GPS results, Tectonophysics, 579, 220-242, https://doi.org/10.1016/j.tecto.2012.03.037, 2012.

Nocquet, J.-M. and Calais, E.: Geodetic Measurements of Crustal Deformation in the Western Mediterranean and Europe, Pure Appl. Geophys., 161, 661-681, https://doi.org/10.1007/s00024003-2468-z, 2004.

Palano, M., González, P. J., and Fernández, J.: Strain and stress fields along the Gibraltar Orogenic Arc: Constraints on active geodynamics, Gondwana Res., 23, 1071-1088, https://doi.org/10.1016/j.gr.2012.05.021, 2013.

Palano, M., González, P. J., and Fernández, J.: The Diffuse Plate boundary of Nubia and Iberia in the Western Mediterranean: Crustal deformation evidence for viscous coupling and fragmented lithosphere, Earth Planet. Sc. Lett., 430, 439-447, https://doi.org/10.1016/j.epsl.2015.08.040, 2015.

Paulatto, M., Watts, A. B., and Peirce, C.: Potential field and high-resolution bathymetry investigation of the Monowai volcanic centre, Kermadec Arc: implications for caldera formation and volcanic evolution, Geophys. J. Int., 197, 1484-1499, https://doi.org/10.1093/gji/ggt512, 2014.
Peacock, D. C. P. and Sanderson, D. J.: Strike-slip relay ramps, J. Struct. Geol., 17, 1351-1360, https://doi.org/10.1016/01918141(95)97303-W, 1995.

Perea, H., Gràcia, E., Bartolomé, R., Gómez de la Peña, L., Martínez-Loriente, S., Moreno, X., De Mol, B., Tello, O., Ballesteros, M., and EVENT-DEEP cruise party: Evidences of quaternary active faults Across the Djibouti high and the Adra Ridge (Alboran Sea), in: Una aproximación multidisciplinar al estudio de las fallas activas, los terremotos y el riesgo sísmico, edited by: Álvarez-Gomez, J. A. and Martín-González, F., Segunda reunión Ibérica sobre fallas activas y paleosismología, Lorca, Murcia, España, 97-100, ISBN: 978-84-617-2049-1, 2014.

Perea, H., Gràcia, E., Martínez-Loriente, S., Bartolome, R., de la Peña, L. G., de Mol, B., Moreno, X., Iacono, C. L., Diez, S., Tello, O., Gómez-Ballesteros, M., and Dañobeitia, J. J.: Kinematic analysis of secondary faults within a distributed shear-zone reveals fault linkage and increased seismic hazard, Mar. Geol., 399, 23-33, https://doi.org/10.1016/j.margeo.2018.02.002, 2018.

Perouse, E., Vernant, P., Chery, J., Reilinger, R., and McClusky, S.: Active surface deformation and sub-lithospheric processes in the western Mediterranean constrained by numerical models, Geology, 38, 823-826, https://doi.org/10.1130/G30963.1, 2010.

Petit, C., Pourhiet, L. L., Scalabrino, B., Corsini, M., Bonnin, M., and Romagny, A.: Crustal structure and gravity anomalies beneath the Rif, northern Morocco: implications for the current tectonics of the Alboran region, Geophys. J. Int., 202, 640-652, https://doi.org/10.1093/gji/ggv169, 2015.

Poujol, A., Ritz, J.-F., Tahayt, A., Vernant, P., Condomines, M., Blard, P.-H., Billant, J., Vacher, L., Tibari, B., Hni, L., and Koulali, A.: Active tectonics of the Northern Rif (Morocco) from geomorphic and geochronological data, J. Geodyn., 77, 70-88, https://doi.org/10.1016/j.jog.2014.01.004, 2014.

Roberts, A.: Curvature attributes and their application to 3D interpreted horizons, First Break, 19, 85-100, 2001.

Rodriguez, M., Maleuvre, C., Jollivet-Castelot, M., d'Acremont, E., Rabaute, A., Lafosse, M., Ercilla, G., Vázquez, J.-T., Alonso, B., and Ammar, A.: Tsunamigenic submarine landslides along the Xauen-Tofiño banks in the Alboran Sea (Western Mediterranean Sea), Geophys. J. Int., 209, 266-281, https://doi.org/10.1093/gji/ggx028, 2017.

Rohling, E. J., Foster, G. L., Grant, K. M., Marino, G., Roberts, A. P., Tamisiea, M. E., and Williams, F.: Sea-level and deep-seatemperature variability over the past 5.3 million years, Nature, 508, 477-482, https://doi.org/10.1038/nature13230, 2014.

Roldán, F. J., Galindo-Zaldívar, J., Ruano, P., Chalouan, A., Pedrera, A., Ahmamou, M., Ruiz-Constán, A., Sanz de Galdeano, C., Benmakhlouf, M., López-Garrido, A. C., Anahnah, F., and González-Castillo, L.: Basin evolution associated to curved thrusts: The Prerif Ridges in the Volubilis area (Rif Cordillera, Morocco), J. Geodyn., 77, 56-69, https://doi.org/10.1016/j.jog.2013.11.001, 2014.

Romagny, A., Münch, P., Cornée, J.-J., Corsini, M., Azdimousa, A., Melinte-Dobrinescu, M. C., Drinia, H., Bonno, M., Arnaud, N., Monié, P., Quillévéré, F., and Ben Moussa, A.: Late Miocene to present-day exhumation and uplift of the Internal Zone of the Rif chain: Insights from low temperature thermochronometry and basin analysis, J. Geodyn., 77, 39-55, https://doi.org/10.1016/j.jog.2014.01.006, 2014. 
Ruiz-Constán, A., Galindo-Zaldívar, J., Pedrera, A., Célérier, B., and Marín-Lechado, C.: Stress distribution at the transition from subduction to continental collision (northwestern and central Betic Cordillera), Geochem. Geophy. Geosy., 12, Q12002, https://doi.org/10.1029/2011gc003824, 2011.

Soto, J. I., Fernandez-Ibanez, F., Talukder, A. R., and MartinezGarcia, P.: Miocene shale tectonics in the Alboran Sea (western Mediterranean), Abstracts with Programs - Geological Society of America, 40, 119-144, 2008.

Soto, J. I., Fernández-Ibáñez, F., and Talukder, A. R.: Recent shale tectonics and basin evolution of the NW Alboran Sea, The Leading Edge, 31, 768-775, https://doi.org/10.1190/tle31070768.1, 2012.

Spakman, W., Chertova, M. V., van den Berg, A., and van Hinsbergen, D. J. J.: Puzzling features of western Mediterranean tectonics explained by slab dragging, Nat. Geosci., 11, 211-216, https://doi.org/10.1038/s41561-018-0066-z, 2018.

Stich, D., Mancilla, F. d. L., Baumont, D., and Morales, J.: Source analysis of the $M_{w} 6.32004 \mathrm{Al}$ Hoceima earthquake (Morocco) using regional apparent source time functions, J. Geophys. Res., 110, B06306, https://doi.org/10.1029/2004JB003366, 2005.

Stich, D., Serpelloni, E., de Lis Mancilla, F. d. L., and Morales, J.: Kinematics of the Iberia-Maghreb plate contact from seismic moment tensors and GPS observations, Tectonophysics, 426, 295-317, https://doi.org/10.1016/j.tecto.2006.08.004, 2006.

Stich, D., Martín, R., and Morales, J.: Moment tensor inversion for Iberia-Maghreb earthquakes 2005-2008, Tectonophysics, 483, 390-398, https://doi.org/10.1016/j.tecto.2009.11.006, 2010.

Storti, F., Soto Marin, R., Rossetti, F., and Casas Sainz, A. M.: Evolution of experimental thrust wedges accreted from along-strike tapered, silicone-floored multilayers, Journal of the Geological Society, 164, 73-85, https://doi.org/10.1144/0016-76492005186, 2007.

Sun, M. and Bezada, M.: Seismogenic Necking During Slab Detachment: Evidence From Relocation of Intermediate-Depth Seismicity in the Alboran Slab, J. Geophys. Res.-Sol. Ea., 125, e2019JB017896, https://doi.org/10.1029/2019JB017896, 2020. ter Borgh, M. M., Oldenhuis, R., Biermann, C., Smit, J. H. W., and Sokoutis, D.: The effects of basement ramps on deformation of the Prebetics (Spain): A combined field and analogue modelling study, Tectonophysics, 502, 62-74, https://doi.org/10.1016/j.tecto.2010.04.013, 2011.

Tesson, M., Gensous, B., and Lambraimi, M.: Seismic analysis of the southern margin of the Alboran Sea, J. Afr. Earth Sci., 6, 813-821, https://doi.org/10.1016/0899-5362(87)90038-8, 1987.

Thurner, S., Palomeras, I., Levander, A., Carbonell, R., and Lee, C.T.: Ongoing lithospheric removal in the western Mediterranean: Evidence from Ps receiver functions and thermobarometry of Neogene basalts (PICASSO project), Geochem. Geophy. Geosy., 15, 1113-1127, https://doi.org/10.1002/2013GC005124, 2014.

Valera, L. J., Negredo, M. A., and Jiménez-Munt, I.: Deep and near-surface consequences of root removal by asymmetric continental delamination, Tectonophysics, 502, 257-265, https://doi.org/10.1016/j.tecto.2010.04.002, 2011.

Vázquez, J. T., Estrada, F., Vegas, R., Ercilla, G., d'Acremont, E., Fernández-Salas, L. M., Alonso, B., Fernández-Puga, M. C., Gomez-Ballesteros, M., Gorini, Ch., Bárcenas, P., and Palomino, D.: Quaternary tectonics influence on the Adra continental slope morphology (Northern Alboran Sea), in: Una aproximación multidisciplinar al estudio de las fallas activas, los terremotos y el riesgo sísmico, edited by: Àlvarez-Gomez, J. A. and MartínGonzález, F., Segunda reunión Ibérica sobre fallas activas y paleosismología, Lorca, Murcia, España, 89-92, ISBN: 978-84-6172049-1, 2014.

Vernant, P., Fadil, A., Mourabit, T., Ouazar, D., Koulali, A., Davila, J. M., Garate, J., McClusky, S., and Reilinger, R.: Geodetic constraints on active tectonics of the Western Mediterranean: Implications for the kinematics and dynamics of the Nubia-Eurasia plate boundary zone, J. Geodyn., 49, 123-129, https://doi.org/10.1016/j.jog.2009.10.007, 2010.

Watts, A. B., Platt, J. P., and Buhl, P.: Tectonic evolution of the Alboran Sea basin, Basin Res., 5, 153-177, https://doi.org/10.1111/j.1365-2117.1993.tb00063.x, 1993. 